\title{
Tragedy, morality and metaphysics
}

\author{
Sebastian Gardner
}

Thought about the relation between tragedy and morality may be divided into two schools. The one, which dominates writing on tragedy, assumes a fundamental compatibility between tragedy and morality. The connection allows of various formulations. It may be held that the experience of tragedy is constituted by moral appraisal, that the telos of tragedy converges with moral ends, or simply that there is at least nothing in the experience of tragedy which disturbs the outlook of morality. The other line of thought, which again comes in different formulations, is that there is on the contrary a dissociation or discrepancy, or in stronger terms, a mutual antagonism, between tragedy and morality. My aim in this paper is to explore one form of the latter view.

The association of tragedy with morality has a long and highly distinguished history. Among theoretical writings favouring tragedy's moral significance we find, after Aristotle's oblique account of the relation, a long and unified tradition stretching from Horace, up over the hiatus of medieval culture, to the eighteenth century. Attempts to extract from Aristotle's Poetics an explicit account of the moral significance of tragedy abound in Renaissance humanism. ${ }^{1}$ The Horatian view

${ }^{1}$ See for example the extracts from Giambattista Giraldi and Lorenzo Giacomini in Michael J. Sidnell ed., Sources of Dramatic Theory (Cambridge: Cambridge University Press, 1991), vol. 1, Plato to Congreve, pp. 123-4, 125, 173-4; and from Bernardino Daniello and Antonio Sebastiano (Minturno) in Barrett H. Clark ed., European Theories of the Drama (New York: Crown, 1965), pp. 40-5. This moral-Aristotelian tradition extends as far as the eighteenth century: see the extracts 
of tragedy as pleasing moral instruction ${ }^{2}$ is taken up in Sir Phillip Sidney’s theory of tragedy as effecting the highest species of morally purposeful imitation, ${ }^{3}$ and echoed in Thomas Rymer's influential writings, where the claim is famously made that tragedy delivers properly clear moral lessons through the representation of 'poetical Justice'.${ }^{4}$ Forthright statements of the moral view are again found in numerous later neo-classical figures, including John Milton, John Dryden, Samuel Johnson and Joseph Addison; ${ }^{5}$ even David Hume, philosophically well positioned to take a light

from Pietro Metastasio in Sidnell ed., Sources of Dramatic Theory, vol. 2, Voltaire to Hugo, pp. 324.

${ }^{2}$ See Ars Poetica, in Horace on the Art of Poetry, ed. Edward Henry Blakeney (London: Scholartis, 1928), 309sqq., 333sqq., 390sqq.

3 'Therefore poetry is an art of imitation [...] with this end, to teach and delight $[\ldots]$ the final end is to lead and draw us to as high a perfection as our degenerate souls [...] can be capable of' (An Apology for Poetry (1595), ed. Geoffrey Shepherd (Manchester: Manchester University Press, 1973), pp. 101-2). Tragedy is 'so excellent a representation of whatsoever is most worthy to be learned' (op. cit., p. 118).

${ }^{4}$ Tragedies of the Last Age, in The Critical Works of Thomas Rymer, ed. Curt Zimansky (New Haven: Yale University Press, 1956), p. 27. See G. B. Dutton, 'The French Aristotelian formalists and Thomas Rymer', Publications of the Modern Language Association of America 29, 1914, $152-$ 88 , pp. $158 \mathrm{ff}$.

${ }^{5}$ Milton describes tragedy as 'the gravest, moralest, and most profitable of all other Poems', while also noting 'the small esteem, or rather infamy, which in the account of many it undergoes at this day', preface to Samson Agonistes (1671), 'Of that sort of Dramatic Poem which is call'd Tragedy', in Poetical Works, ed. Rev. H. C. Beeching (Oxford: Oxford University Press, 1919). Dryden defines drama in general as 'A just and lively image of human nature, representing its passions and humours, and the changes of fortune to which it is subject, for the delight and instruction of 
view of the moral service of art, makes it a condition on the proper functioning of tragedy that it should not strain our moral dispositions. ${ }^{6}$ The same outlook, in an even more pronounced form, characterises French and German neo-classical criticism. François Hédelin (Abbé D’Aubignac) declares that the overriding aim of the dramatist is verisimilitude, comprehending moral conditions and purposes $;{ }^{7}$ Pierre Corneille conceives tragedy as enforcing the sovereignty of reason and hence of morality over the passions $;{ }^{8}$ Jean Racine interprets tragic pity and terror as tempering and

mankind' ('An essay of dramatic poesy' (1688), in D. J. Enright and Ernst de Chickera eds., English Critical Texts: 16th Century to 20th Century (Oxford: Clarendon, 1962), p. 55).

6 ‘Of tragedy' (1741), in Essays: Moral, Political and Literary (London: Grant Richards, 1903), p. 229.

${ }^{7}$ See the extracts from La pratique du théatre (1657), in Sidnell ed., Sources of Dramatic Theory, vol. 1, pp. 220-33: 'Drama does not show things as they are, but as they ought to have been' (p. 224), for which reason the crimes of monarchs may not be represented; drama imitates human actions in order to teach, and in the case of 'maxims pertaining to moral conduct', 'this must be done indirectly, and by means of actions': 'if the dramatic action is clear and well-constructed, it will show the power of virtue shining out [...] [even when overcome, it] always remains admirable', while vice 'even when it triumphs by violence, never ceases to be abominable. Hence the spectators draw their own conclusion, quite naturally, that it is better to embrace virtue at the risk of suffering injustice' (p. 232).

${ }^{8}$ Discours I (de l'utilité et des parties du poème dramatique) and II (de la tragédie et des moyens de la traiter selon le vraisemblance ou le nécessaire) (1660), in Writings on the Theatre, ed. H. T. Barnwell (Oxford: Blackwell, 1965), I, pp. 3-7, II, pp. 29, 32, 34. 'Horace nous apprend que nous ne saurions plaire à tout le monde, si nous n'y mêlons l'utile [...] quoique l'utile n'y entre que sous la forme du délectable, il ne laisse pas d'y être nécessaire' (pp. 3-4). Corneille modifies Aristotle: 
refining our passions in order to set them in conformity with morality and reason. ${ }^{9} \mathrm{~J}$. Chr. Gottsched pleads for the inclusion of tragedians in a well-ordered society on the grounds that tragedy provides, through its palpable exemplification of vice and virtue, one of the most powerful stimuli to morality, on a par with the exhortations of the clergy; ${ }^{10}$ Gotthold Lessing claims that tragedy induces pity and fear in such a way as to transform these passions into virtues. ${ }^{11}$ Moses Mendelssohn advances a theory of the pleasure in tragedy as due to awareness of the moral character of one's own responses: again, tragedy fosters the perfections of the soul. ${ }^{12}$

he rejects purgation through joint pity and fear as improbable, holding instead that either pity or fear will suffice to deter us from the relevant vicious passion.

${ }^{9}$ Principes de la tragédie en marge de la poétique d'Aristote, ed. Eugène Vinaver (Paris: Nizet, 1959), p. 12.

${ }^{10}$ Gottsched, 'Die Schauspiele und besonders die Tragödien sind aus einer wohlbestellten Republik nicht zu verbannen', in Schriften zur Literatur (Stuttgart: Reclam, 1972).

${ }^{11}$ See Hamburgische Dramaturgie (1767-68), in vol. 6 of Gesammelte Werke, ed. Paul Rilla (Berlin: Aufbau-Verlag, 1968), Stück 78. The role of the dramatist is 'to enlighten and improve' (Stück 1, p. 15); theatre is to provide a 'school of the moral world' (Stück 2, p. 16). This is achieved by presenting objects in their true moral light, so as to shape appropriately our desires and dispositions (Stück 34, p. 177), and by the transformation of pity and fear into virtues (Stück 78, p. 399).

12 'Rhapsody or additions to the letters on sentiments' (1761), in Philosophical Writings, ed. Daniel O. Dahlstrom (Cambridge: Cambridge University Press, 1997). 
With romanticism, discussion of tragedy changes tone and direction, as new issues, such as the genius of Shakespeare and the organic, rule-defiant character of art, come into focus $;^{13}$ but the moral view continues to be upheld, albeit in forms that are, compared with neo-classical formulations, relatively complex. Thus we find in Friedrich Schiller an account of tragedy as hinging on moral choice in the face of suffering, and in G. W. F. Hegel a non-Aristotelian conception of tragedy as concerned with the self-rationalisation of the ethical. The critical writings of the major romantic figures typically presume an undivided Good which comprehends morality and to which tragedy contributes. ${ }^{14}$ If the moral view of tragedy becomes thereafter less prominent, it is chiefly because of the accelerating modernist impulse to grant art its autonomy; Bertolt Brecht stands out as an exception. ${ }^{15}$ This does not however prevent the moral view from pervading modern thought about tragedy; the assumption that tragedy serves to enhance moral sensibility is visible in much humanist literary criticism.

${ }^{13}$ See Jonathan Bate ed., The Romantics on Shakespeare (Harmondsworth: Penguin, 1992), and Samuel Taylor Coleridge, Criticism of Shakespeare: A Selection, ed. R. A. Foakes (London: Athlone, 1989).

${ }^{14}$ See e.g. Coleridge, op. cit., pp. 57-8, and Percy Bysshe Shelley, 'A defence of poetry’ (1840 [1821]), in Selected Poetry and Prose, ed. Harold Bloom (New York: Signet, 1966) (discussed below).

${ }^{15}$ See Brecht on Theatre: The Development of an Aesthetic, trans. John Willett (London: Methuen, 1982), pp. 29-31, 36-7, 69ff. Brecht regards the concept of tragedy as a historical relic (p. 66), but his pedagogic conception of 'major' drama and his preparedness to utilise emotional responses to representations of suffering (pp. 71, 186) puts him firmly in a line of descent from the seventeenthand eighteenth-century Horatians: right action is to be fostered by knowledge of how the world works, of Providence or (for Brecht) of social processes. 
In some of these cases the moral significance of tragedy is held to derive simply from a supposed general consonance of art with morality, while in others, of greater interest, the connection is attributed to the specific features which differentiate tragedy from other forms of art, and no general position on the art/morality relation is strictly presupposed, though it is in most cases it is present. The moral view does not, it should be stressed, presuppose a didactic conception of tragedy, i.e. the view that tragedy is either intentionally designed or justified only as a means of moral instruction: all it need assert is the teleological harmony of tragedy with morality.

Representing the opposite view, that of the minority, is above all Friedrich Nietzsche (though I shall suggest that it is implicit, if no more, in some other tragic theorists too). The original immoralisation of tragedy belongs, of course, to Plato, but just as the affirmation of tragedy's moral value is less interesting when asserted merely on the basis that tragedy is an instance of (representational) art in general, so Plato's attack on tragedy's moral standing, which rests on no distinction between tragedy and other emotion-arousing artistic representations, is not of primary interest in the present context.

At first glance, measuring the unequal historical balance of the two sides, and taking note of the widely different starting points of the writers who suppose tragedy to agree with morality, it can seem that all plausible roads lead surely and firmly to the conclusion that tragedy has a moral dimension, and that one will come to think otherwise only if one holds some eccentric general position on the nature of value or of art, as Plato and Nietzsche, in their different ways, may be thought to have done. What I will attempt to argue, however, is that the notion of an antagonism between tragedy and morality is highly plausible, for reasons that are in the spirit of Nietzsche and entirely consistent with our experience of tragedy.

An exhaustive treatment of the myriad different ways in which the connection of tragedy with morality has been conceived is out of the question. Consequently I will instead, in the first part of this paper, after some preliminary criticism of the moral view of tragedy, try to give positive reason for thinking that the perspectives of tragedy and morality conflict. This argument is intended 
to stand on its own, but it receives additional support from the metaphysical account of tragedy which I sketch in the second part of the paper.

\section{I}

The fact that tragedy is no peripheral or transient artistic phenomenon, but has an abiding place in Western culture, central to which is an explicit concern for morality, may be thought to provide an initial and obvious reason for supposing that there must be some sort of agreement of tragedy with morality.

Further reasons of a plain type for presuming the agreement of tragedy and morality may be advanced. The creation and appreciation of tragedy cannot itself be regarded with any plausibility as a moral wrong. No interpretation of tragedy which assigned it the same immoral or morally dubious status as gladiatorial combat or pornography would be remotely tenable. Tragic works do not represent vicious acts as desirable or as proper objects of delight. When we take pleasure in tragedy, we do so with a good conscience; we know, as far as we ever can, that our pleasure is not sadistic. Furthermore, the focus of tragedy, like that of morality, is on the most important human concerns, moral characterisation of which can scarcely be avoided in tragic representation. And since the import of tragedy, whatever it may be exactly, is that the human good is liable to destruction, it may consequently be supposed that, since tragedy both heightens our awareness of this good, and makes us fear for its destruction, the dispositions engendered by tragedy will be precisely moral ones.

These points help to circumscribe the territory on which the conflict of tragedy with morality, if there is one, might be found. The quickest and easiest way to set up a conflict, of a minimal sort, between tragedy and morality, would be to claim simply that the end of tragedy is independent of and capable of conflicting contingently with some moral end. A theory which says that the purpose of tragedy is either pleasure or aesthetic value, formalistically conceived, will do this. Hedonistic or aestheticist theories of tragedy are, however, highly improbable: of all the 
species of art, tragedy has the least straightforward connection with pleasure, and tragic works are the hardest to reduce to self-subsistent aesthetic objects. ${ }^{16}$ The notion that tragedy conflicts with morality is worth exploring, it would seem, only if the point of tragedy is identified with something other than either pleasure or formalistic aesthetic value. We should accordingly proceed on the assumption that the purpose of tragedy lies in what it says about human life, and that this is what leads it into conflict with morality.

It is not necessary, in order for tragedy to do this, that it should directly contradict moral evaluations. Tragedy may conflict with morality without inculcating immoralism, answering to vicious dispositions, or giving reason for immoral action. The conflict may lie instead, more subtly, in the view of the world and our place in it which is formed in the course of appreciating tragedy: this view may be inconsistent with that which we maintain qua moral agents; the tragic conception of value may be inconsistent with the moral good. Thus even if there is no difference between the actions to which tragedy leaves us disposed and those which we approve morally, it does not follow that tragedy generates or consolidates moral dispositions: it is entirely possible for conflicting values to enjoin the same actions, and in any case it is quite possible that tragedy delineates values without forming any dispositions to action at all.

Nor can the agreement of tragedy with morality be inferred from the cultural esteem accorded to tragedy. Human culture is not a rigidly integrated system of ends, and cultural practices may co-exist without sharing a common subjective ground. Nor can anything be inferred safely from the absence of any perceived incompatibility of tragedy and morality on the part of the spectator: both because we may be unaware, pre-theoretically, of the deeper implications of the understanding we form in tragedy, and because there may be contextual reasons why the conflict is

\footnotetext{
${ }^{16}$ A hedonistic account of the value of tragedy is given in Ludovico Castelvetro's commentary on Aristotle; see the extracts in Sidnell ed., Sources of Dramatic Theory, vol. 1, pp. 132, 134-5, 141-2,
} 143. 
veiled from us. And again, the moral subject-matter of tragedy is no guarantee of tragedy's moral purposiveness: the fact that tragedy employs moral characterisations of persons and actions does not mean that tragedy is concerned with promoting the value of those characterisations. It is quite possible that, although morality is employed in the construction of tragic representations, the features of those representations which make them tragic are not moral ones, so that, to the extent that tragedy does take us inside moral issues, this is simply part and parcel of its construction of a fictional world of a kind which allows tragedy to make its own, non-moral point. In short, the representation of moral depth in tragedy may be a means to, or concomitant of, an end which conflicts with morality. The property of representing things which have a moral nature is distinct from that of advancing moral ends.

Examination of the more obvious reasons for supposing the agreement of tragedy and morality yields, therefore, only a very thin sense in which this must be so: namely, enjoyment of tragedy is not inherently immoral and tragedy does not promote any practical ends which set it at variance with morality. It remains an open question whether the perspective or world-view expressed in tragedy - the 'look' that it gives to the world - coheres with that of moral agency, and whether tragic and moral value are compatible.

Turning to the philosophical and historical literature, we find that, while the moral conception of tragedy is frequently stated, detailed support for it is not abundant. As observed earlier, the moral significance of tragedy is often supposed to derive from a presumed general link of art with morality. This is inconclusive, however, due to the possibility that tragedy, as an exceptional form of art, is an exception to the rule: it needs to be shown that the features of art which in general link it to morality are present, and not overridden, in tragedy. The bulk of writings on tragedy in each age tend to devote space to other, more pressing issues: the question of compatibility with Christian doctrine, the relation of modern to ancient dramatic poetry, the relative merits of English and French tragedy, questions of craft and technique such as the importance of the 
unities, the integrity of tragi-comedy, the relation of plot to character, and so forth. ${ }^{17}$ Of the writers referred to above, only Aristotle, Schiller and Hegel offer anything extensive on the link of tragedy with morality, and in all three cases there are limitations to the scope of their discussions, Aristotle's deriving from the notorious obscurity of katharsis. Problems with Schiller and Hegel will be discussed later.

Two historically common lines of argument for the moral view of tragedy, particularly salient in neo-classical criticism, may nevertheless be singled out. One is that tragedy represents for our edification the morally proper consequences of virtue and vice (poetical Justice). The other is that tragedy's arousal of emotion is morally beneficent. Rymer writes: 'besides the purging of the passions; something must stick by observing that constant order, that harmony and beauty of Providence, that necessary relation and chain, whereby the causes and the effects, the vertues and rewards, the vices and their punishments are proportion'd and link'd together; how deep and dark soever are laid the Springs, and however intricate and involv'd are their operations'. ${ }^{18}$ Similarly, Dryden asserts that in tragedy, as compared with comedy, 'the laws of justice are more strictly to be observed; and examples of punishment to be made to deter mankind from the pursuit of vice [...]

${ }^{17}$ See Raymond Williams, Modern Tragedy (London: Chatto \& Windus, 1966), ch. 1. In analytic philosophy, it may be added, the alleged hedonic paradox of tragedy - attractive as a philosophical topic because of its continuity with other conceptually puzzles in the philosophy of mind (akrasia, belief/emotion anomalies such as those implied by affective response to fictional objects, etc.) seems to have played this role.

${ }^{18}$ Tragedies of the Last Age, p. 75; Rymer complains of Othello that its force is to 'envenome and sour our spirits, to make us repine and grumble at Providence', A Short View of Tragedy (1692), p. 161. 
Thus tragedy fulfils one great part of its institution: which is, by example, to instruct. ${ }^{19}$ And Johnson: 'the design of tragedy is to instruct by moving the passions' ${ }^{20}$ Tragedy, Joseph Addison writes, is 'one of the most delightful and most improving Entertainments': tragic dramas 'cherish and cultivate that Humanity which is the Ornament of our Nature. They soften Insolence, sooth Affliction, and subdue the Mind to the Dispensations of Providence. ${ }^{21}$

Without entering into the detail, it is not hard to see the limitations of these accounts. The claim that tragedy represents the world as exhibiting a moral order in the specific sense of a causal power to reward virtue and punish vice, or as being at least not indifferent in this respect, is perhaps the least defensible version of the moral view. A. C. Bradley disposes of it with respect to Shakespearean tragedy by showing that, if we gauge the world of Shakespearean tragedy in such terms, then we do discover it to be intolerant of evil, but to a degree that is pathological and, paradoxically, immoral - any slight disturbance of the moral equilibrium produces convulsions which in turn destroy virtue and innocence. ${ }^{22}$

19 'Preface to An Evening's Love' (1671), in Of Dramatic Poesy and Other Critical Essays, vol. 1, ed. George Watson (London: Dent, 1962), pp. 151-2.

${ }^{20}$ The Rambler, no. 156, in Selected Essays from the Rambler, Adventurer, and Idler, ed. W. J. Bate (New Haven: Yale University Press, 1968), p. 196.

${ }^{21}$ The Spectator (with Richard Steele and others), ed. Donald F. Bond (Oxford: Clarendon, 1965), no. 39 (1711). Addison however departs from orthodoxy by rejecting the rule of poetic justice, arguing that it provides virtue with a sense of security that defeats the point of tragedy (op. cit., no. 40, 1711).

${ }^{22}$ Shakespearean Tragedy, pp. 23-9. Roughly the same point is made by Clifford Leech: even if tragedy reveals some moral order in the world, it is too little for the tragic affirmation to be understood as an affirmation of morality in the sense of an expression of moral confidence, confidence in the power of the moral Good ('The implications of tragedy', in Laurence Lerner ed., 
The second line of thought, that arousing pity and fear purges or neutralises morally harmful passions, or, in a sentimentalist version, that tragedy induces morally purposeful sympathetic feeling, ${ }^{23}$ fails to secure a firm relation to morality. Even if the relevant lines of psychological causation are granted to be reliable, an essential attunement of tragedy with morality follows only if a reductive, psychologistic view of both tragedy and morality is assumed. If anything other than states of feeling enters the process - if the upshot of pity and fear is mediated by reflection, or if morality requires not just the occurrence of sympathy but also its interpretation - then a moral end will not necessarily be achieved.

Whereas the first argument takes an unsustainable view of the objective content of tragedy, the second argument attends only to its subjective effects and takes too narrow a view of these.

The first modern philosophical age to have been well positioned to address directly the question of tragedy's relation to morality - on account of its heritage of Hellenism unmediated by Christianity, its preoccupation with the questions of the foundation of morality and the significance of aesthetic experience, and its ambition to construct a comprehensive philosophical system - is German idealism, and it is significant for my account that the German idealist tradition of reflection on tragedy, though committed to integrating tragedy with morality, should culminate historically in

Shakespeare's Tragedies: An Anthology of Modern Criticism (Penguin: Harmondsworth, 1968), pp. 288-9).

${ }^{23}$ See William K. Wimsatt and Cleanth Brooks, Literary Criticism: A Short History (New York: Knopf, 1964), pp. 291-7. The sentimentalist view may be found in Edmund Burke, A Philosophical Enquiry into the Origin of our Ideas of the Sublime and the Beautiful (1757), ed. James Boulton (Oxford: Blackwell, 1987), pt. 1, sects. 12-13: tragedy exercises sympathy, a passion which serves ends in 'the great chain of society'. In one variant it is an element in Shelley's A Defence of Poetry: 'The great instrument of the moral good is the imagination [...] Poetry strengthens the faculty which is the organ of the moral nature of man' (pp. 424-5). 
Nietzsche's The Birth of Tragedy. The non-agreement of tragedy with morality is not the central thesis in this early work of Nietzsche's - it becomes fully clear only in his later writings - but it is one of its important themes: the conflict results from the opposition of pessimistic, Dyonisiacincorporating tragedy, to the optimistic, rationalistic, Socratic consciousness with which Nietzsche here already associates Christian and modern morality. ${ }^{24}$ Instead of examining directly the argument

${ }^{24}$ See The Birth of Tragedy (1872), trans. Shaun Whiteside, ed. Michael Tanner (Harmondsworth: Penguin, 1993), §22, opposing the aesthetic-Dyonisiac to the moral-Aristotelian interpretation of tragedy; and Robert Pippin, 'Truth and lies in the early Nietzsche', in Idealism as Modernism: Hegelian Variations (Cambridge: Cambridge University Press, 1997), pp. 315-16, 327-8. In Nietzsche's later writings the antithesis of morality and tragedy is drawn more sharply: see Human, All Too Human (1878), trans. R. J. Hollingdale (Cambridge: Cambridge University Press, 1986), §212; Daybreak: Thoughts on the Prejudices of Morality (1881), trans. R. J. Hollingdale (Cambridge: Cambridge University Press, 1982), §78, §172, §240; The Gay Science (1882), trans. Walter Kaufmann (New York: Vintage, 1974), §107, §135; Beyond Good and Evil: Prelude to a Philosophy of the Future (1886), trans. Walter Kaufmann (New York: Vintage, 1966), §229; On the Genealogy of Morals (1887), trans. Walter Kaufmann and R. J. Hollingdale (New York: Vintage, 1969), Second Essay, sect. 7; Ecce Homo (1888), trans. R. J. Hollingdale (Harmondsworth: Penguin, 1979), 'The Birth of Tragedy'; Twilight of the Idols: or How to Philosophize with a Hammer (1889), trans. R. J. Hollingdale (Harmondsworth: Penguin, 1968), 'Expeditions of an untimely man', §24, 'What I owe to the ancients', §5; the 'Attempt at a self-criticism' prefaced in 1886 to The Birth of Tragedy, §§4-5; and The Will to Power, trans. Walter Kaufmann and R. J. Hollingdale (New York: Vintage, 1968), §§851-3. The Birth of Tragedy raises up tragedy against a cultural and spiritual condition of which (Christian) morality is a central component, but tragedy clashes with morality only in so far as (Christian) morality is a part of the general modern condition which tragic consciousness opposes. Later, when morality has become for Nietzsche the root cause 
of The Birth of Tragedy, which is long and convoluted, I will try to articulate, with reference to earlier developments in German philosophy, a line of thought which provides a partial reconstruction of Nietzsche's reasons for thinking of tragedy and morality as opposed.

One of the several variables complicating the issue of tragedy's relation to morality is, as noted at the outset, the strength of the association or conflict with morality envisaged. Another is the strength of the conception of morality employed by the moral view of tragedy: the less demanding the conception, the easier it will be to show its agreement and the harder its conflict with tragedy, though at the same time, the less philosophically interesting the association is likely to be. ${ }^{25}$ In order for the argument to get started, something about the content of morality needs to be presupposed. I will consequently begin by sketching a conception which is sufficiently strong to make the moral view of tragedy worth defending, but not so inflated as to provide the Nietzschean view with a straw man.

Considered as nothing more than a set of normative principles or states of character for effecting states of affairs in the world, morality could only be contradicted by tragedy if the latter did what, it was conceded above, it does not do, viz. promote actions (or pleasures) contrary to those enjoined by morality. Morality considered in this way is, however, morality considered without reference to either its ground, that which gives it normative force, or what may be called its

of the modern life-deficiency, he no longer regards tragedy as an adequate alternative to morality. Thus Nietzsche valorises tragedy at an early point, when he does not see morality as a special, fundamental problem; and at the later point when he does see morality as such a problem, his estimate of the curative power of tragedy has declined.

${ }^{25}$ Yet another is the assumed scope of the genre - whether it is historically circumscribed, whether any historical age or ages should be regarded as paradigms of tragedy, and which if any nondramatic (or even non-representational) arts may include tragic works. My discussion aims to bypass these issues as far as is possible. 
world-characterisation, that is, the general character which it assigns to the world qua background to and context of moral action. It is unnecessary for either to figure as part of the content of firstorder moral principles or of virtuous sentiment and reflection, but each is nevertheless an essential element of morality, the world-characterisation being a component, explicit or implicit, of the broader, metaphysical picture deployed in the justification of morality. Evidently, it is with respect to the world-characterisation of morality that its conflict with tragedy may be thought in the first instance to arise.

The assumption that morality is committed to a world-characterisation, it should be noted, is important for the moral view of tragedy, if this view is to be formulated convincingly. Once it has been recognised that the contribution of tragedy to morality cannot be held to consist in the portrayal of poetical Justice, nor in the activation of sympathy, the options are rather narrow. It would not be plausible to hold that the purpose of tragedy is to represent morally right things as desirable and morally wrong things as undesirable: the bulk of tragic works can scarcely be read as having it as their primary aim to extol the value of moral values. In order for the moral view of tragedy to be formulated plausibly, the consonance of tragedy with morality needs to be subtler, and so it is natural to suppose that it must occur by way of their respective world-characterisation.

If morality characterises the world, what character does it then give it? Underlying all of the various world-characterisations provided by different moral systems from Aristotle to G. W. Leibniz and the Earl of Shaftesbury, there is arguably a constant, universal assumption concerning the character of the world which moral consciousness needs to make, and which derives from the basic consideration that morality is the property of finite agents, who need to think of the world in morally congenial, morally purposive, terms. As Immanuel Kant expresses it:

Consider the case of a righteous man (one like Spinoza) who is firmly persuaded that there is no God and (the consequence being the same as far as the object of morality is concerned) that there is also no future life: What view will he take of his own inner purpose, determined 
as it is by the moral law which he actively reveres? He does not require that compliance with the law should carry any advantage for him, either in this or in another world; selflessly, he wants only to promote the good to which that holy law directs all his powers. But his efforts encounter limits; and all he can expect from nature is that it will now and again contribute contingently to the purpose that he feels himself obligated and drawn to achieve, never that it will harmonize with it in a way governed by laws and constant rules (as his inner maxims are and must be) [... A]nd the other righteous people that he encounters, no matter how worthy of happiness they may be, will be subjected indifferently by nature to all of the evils of deprivation, disease and untimely death, like all the other animals of the earth, and they will remain subject to these evils until one wide grave swallows them up (whatever their degree of rectitude) and throws them - they who managed to believe themselves to be the ultimate purpose of creation - back into the abyss of purposeless chaos of matter from which they were drawn. This well-meaning person would quite certainly have to renounce as impossible the purpose that the moral law placed before his eyes $[\ldots]^{26}$

\begin{abstract}
'Alternatively', Kant continues, the righteous man may 'form a concept of the possibility' of achieving his moral purpose by postulating a moral ground of nature, and 'from a practical point of view', this conception 'must' be formed. ${ }^{27}$ Thus, on Kant's account, the necessity of a (theological) world-characterisation is due to the need, not to determine which actions are morally required, but
\end{abstract}

${ }^{26}$ Kritik der Urteilskraft (Critique of Judgement) (1790), in vol. 5 of Kants gesammelte Schriften, ed. Königlich Preußischen Akademie der Wissenschaften (Berlin: 1900-), §87, 452.

${ }^{27}$ Op. cit., $§ 87,452$. The view is expressed even more forcibly in J. G. Fichte, 'On the basis of our belief in a divine governance of the world' (1798), in Daniel Brezeale ed., Introductions to the Wissenschaftslehre and Other Writings (1797-1800) (Indianapolis: Hackett, 1994), esp. p. 152. 
to supply the necessary teleological framework for a will governed by pure practical reason in a being which is finite, has constitutively an empirical aspect, and for whom purposiveness is a condition of action. ${ }^{28}$

The notion that morality generates a world-view is formulated explicitly by Hegel in the section of the Phenomenology of Spirit where he gives a critical exposition of Kant's (and J. G. Fichte's) moral theory. Here Hegel describes a different, more abstract route to the conclusion that moral consciousness constrains how the world is conceived. The contrast between what $i$ s the case, and what ought to be the case, which is fundamental to moral consciousness - and which KantFichte enshrine as an absolute in the form of the principle of duty - gives rise to the problem of coordinating the two spheres, of saying how Is and Ought are to be conceived together. This, according to Hegel, is the true problem which leads Kant from morality to theology: duty on the one hand, and Nature on the other, present themselves as independent and mutually indifferent, and each as absolute; a contradiction that Kant tries to resolve by postulating a moral author of the world. ${ }^{29}$ Hegel does not, of course, himself endorse the Kantian-Fichtean 'Moral world-view', indeed his aim is to show that it fails to overcome the contradiction; but he both accepts that his predecessors' philosophy articulates correctly the aspect of moral consciousness which is expressed (in isolation, whence its deficiency) in what Hegel calls Moralität, and he is himself committed to pursuing the same task of showing, with respect to his own conception of morality, how it expands legitimately into a world-characterisation. The point to be retained from Hegel's discussion is therefore that moral consciousness, operating under its own steam, is bound to generate the Kantian characterisation of the world as capable of providing compensating for the moral indifference of nature, a representation which rests in turn on the deeper characterisation of the world as a unity of

\footnotetext{
${ }^{28}$ As I have argued in 'Value and idealism', in Anthony O'Hear ed., Philosophy, the Good, the True and the Beautiful (Cambridge: Cambridge University Press, 2000).

${ }^{29}$ Phenomenology of Spirit (1807), trans. A. V. Miller (Oxford: Clarendon, 1977), §§ 599-600.
} 
ought and is, a single reality in which moral value (or whatever provides its ground: God, perfect being, Reason, Nature, etc.) is contained. ${ }^{30}$

The notion, which these brief references to Kant and Hegel are intended only to illustrate, but which may be considered independently plausible, is that there is an inherent tendency for moral consciousness, by virtue of its internal rationality rather than as a merely psychological matter, to conceive the world in terms that secure the objective purposiveness and well-foundedness of moral action, and that at the extreme, moral consciousness will conceive the world as having morality as its essence and nature as having the facilitation of the moral will as its ultimate purpose. The moral view of tragedy which flourished in the seventeenth and eighteenth centuries has therefore a firm root in moral consciousness: if art is conceived as imitation, and its object, Nature, is conceived within the perspective of morality, i.e. as comprehending Ought as well as $I s$, then the neo-classical view of tragedy as the imitation of an action in which justice is shown to be done, or in which moral truth is in some more oblique manner represented, follows directly.

Now assuming it to be the case that moral consciousness tends inherently in the direction of the world-characterisation just described, the conflict of morality with tragedy can be seen directly.

\footnotetext{
${ }^{30}$ It is of course also a central thesis of Nietzsche's, that Christian-modern moral consciousness makes itself possible only on the basis of a world-characterisation, the destruction of which renders it unsustainable. In On the Genealogy of Morals Nietzsche traces back the co-development of morality and its world-characterisation to the necessity of inventing a meaning for suffering (op. cit., Essay Three, sect. 28). Up to a point this echoes Kant's notion of compensation for the moral meaninglessness of nature, but Nietzsche's view of the relation of morality to its supporting worldview is importantly different from that of Kant, and Hegel, in the following, obvious respect: whereas for Kant-Hegel, the moral world-view evolves out of moral consciousness through rational necessity, in a single logical move, for Nietzsche the process involves numerous non-rational, psychological vicissitudes.
} 
Fundamental to tragedy is the sense of an opposition between human beings and the world at large, this 'other' of humanity assuming various determinate forms (the gods, Necessity, Fate or Fortune, Nature etc.), but in all cases presenting itself as antagonistic to humanity: the world is regarded not as furthering but rather as negating, and as lacking any inner accord with, the attempts of human beings to realise value. ${ }^{31}$ This is not to say that the standard pattern in tragedy is a simple conflict of the hero with his world, ${ }^{32}$ but that, to the extent that the hero makes a contribution to his own destruction, it will be experienced by him, and by us, as reflecting the quality of the world - the destruction which follows from his tragic fault will seem to have been engineered by the world, or at least to reflect its complicity. ${ }^{33}$ Of course, it remains possible to reconcile the vision of tragedy

${ }^{31}$ See Bernard Williams, Shame and Necessity (Berkeley: University of California Press, 1993), pp. 164-5: 'Greek tragedy refuses precisely to present human beings who are ideally in harmony with their world, and has no room for a world that, if it were understood well enough, could instruct us how to be in harmony with it. There is a gap between what the tragic character is, concretely and contingently, and the ways in which the world acts upon him. In some cases, that gap is comprehensible, in terms of conflicting human purposes. In other cases, it is not fully comprehensible and not under control.'

${ }^{32}$ As A. C. Bradley notes, 'the idea of the tragic hero being destroyed simply and solely by forces is quite alien' to Shakespearean tragedy (Shakespearean Tragedy: Lectures on Hamlet, Othello, King Lear, Macbeth (1904) (London: Macmillan, 1974), pp. 14-15).

${ }^{33}$ As Bradley puts it, 'character itself contributes to these feelings of fatality [...] why is it that a man's virtues help to destroy him'? (op. cit., p. 21). Bradley agrees that, because 'the tragic fact' 'remains to us something piteous, fearful and mysterious', 'the ultimate power in the tragic world is not adequately described as a law or order which we can see to be just and benevolent - as, in that sense, a "moral order": for in that case the spectacle of suffering and waste could not seem to us so fearful and mysterious as it does' (op. cit., p. 18). In this connection see also - indicating how the 
with the moral world-characterisation simply by declaring the tragic apprehension of our situation to be incomplete, a partial expression of our experience unrefined by reflection. But in so far as we remain within the perspective of tragedy - in so far as tragic representations are accepted as total, and the experience of tragedy is treated as a sufficient datum from which to extrapolate a metaphysics ${ }^{34}-$ the contradiction exists.

The discrepancy of tragedy with the moral world-characterisation can be brought out by considering what would be required for a representation of the same sort of material as is treated of in tragedy to conform to moral consciousness: in other words, what a 'tragedy' reflecting the worldcharacterisation of morality would look like. This need not be left to the imagination, for there is in Schiller a detailed and rigorous application of Kant's philosophical system to tragedy, which serves precisely this purpose.

Tragedy is, according to Schiller, 'the particular art that establishes the pleasure of sympathy as its purpose', ${ }^{35}$ and we take pleasure in tragedy 'by virtue of the relation to morality', the pleasure antagonism to humanity represented in tragedy brings it into conflict with forms of consciousness other than the moral - Erich Heller's account of Goethe's inability to reconcile tragedy with his quasi-pantheistic sensibility, in 'Goethe and the avoidance of tragedy', in The Disinherited Mind: Essays in Modern German Literature and Thought (London: Bowes \& Bowes, 1975).

${ }^{34}$ Michael Tanner proposes this transcendental mode of argument as a way of understanding The Birth of Tragedy, suggesting that Nietzsche is concerned with the conditions of possibility of tragic experience, in Nietzsche (Oxford: Oxford University Press, 1994)

p. 10.

35 'On the art of tragedy' (1792), in Essays, ed. Walter Hinderer and Daniel O. Dahlstrom (New York: Continuum, 1993), p. 6. The position which Schiller adopts here, under the influence of Kant, differs from the more conventional eighteenth-century view of the moral effect of tragedy taken in Schiller's earlier essays (in Sidnell ed., Sources of Dramatic Theory, vol. 2, pp. 155, 156-60, 165). 
being 'greater in minds that are moral' ${ }^{36}$ Specifically, it is the opposition of morality to sensuous life - inclination, desire - which 'is the condition for igniting that power of mind, whose activity produces the pleasure that we take in sympathetic suffering'. ${ }^{37}$ This ignition occurs as follows: in every tragic emotion some contrapurposiveness [Zweckwidrigkeit] is represented, but pleasure ensues nonetheless whenever a higher purposiveness, which is necessarily that of morality, is represented by us as subsuming it. ${ }^{38}$ Tragedy supplies this higher representation. By this means our eyes are opened to the following vision of the world:

dissatisfaction with fate falls to the wayside, losing itself in the presentiment or rather in a distinct consciousness of a teleological connection among things, a sublime order, a benevolent will. Then, allied with our pleasure in moral harmony there is the invigorating image of the most perfect moral purposiveness in the entire expanse of nature. Its apparent violation, which in a single case caused pain, becomes simply a goad to our reason to search out general laws for a justification of this particular case and to resolve the isolated dissonance within the grand harmony. ${ }^{39}$

As Schiller develops his position, its difficulties become clear. First, since tragedy for Schiller pertains exclusively to the confrontation of our moral with our natural being, no place

36 'On the art of tragedy', p. 4.

${ }^{37}$ Op. cit., p. 5.

${ }^{38}$ Op. cit., p. 7.

${ }^{39}$ Op. cit., p. 9. Note how virtually the same conception is expressed in the quotation from Rymer on page 000 . The difference between Schiller and neo-classical 'poetical Justice' theory is that the latter conceives the providential vision as directly represented within the tragic work, while Schiller regards it as supplied and, as it were, read into the work, by the 'morally formed' spectator. 
remains for anything outside the perspective of finite rational agency. Thus Schiller is forced to claim that even 'the most splendid pieces of the Greek stage leave something to be desired', because they appeal to necessity in place of reason. ${ }^{40}$ Properly, according to Schiller, tragedy takes the form of a drama where practical reason, not external necessity, is what alone leads to loss and suffering: tragedies where 'the misfortune springs, not from immoral sources, but rather from external things that have neither a will nor are subject to one ${ }^{41}$ comprise an inferior form of the genre.

Second, even if we accept that the canon should undergo this revision, Schiller's account seems to demand an even more radical alteration to our conception of what constitutes a proper subject for tragedy. If it is moral purposiveness that provides the source of our pleasure in tragedy, ${ }^{42}$ why are the paradigms of tragedy not simply representations of agents engaged in willing the moral good against the odds? Since the quintessence of tragedy, Schiller's theory implies, lies in representations of moral striving having nothing to do with fate, or with suffering deriving from causes other than the protagonist's choice of the moral good, ${ }^{43}$ it is unexplained why tragic works are not exclusively ones in which we witness either virtue remaining intact under pressure or moral self-sacrifice.

Third, Schiller's account makes tragic experience indistinguishable in essence from experience of the sublime as construed by Kant (non-accidentally, since it is Kant's moral account of the sublime, as Schiller makes clear, which provides the model for his analysis of tragedy). On

\footnotetext{
${ }^{40}$ Op. cit., p. 9.

${ }^{41}$ Op. cit., p. 8.

${ }^{42}$ Op. cit., p. 8.

${ }^{43}$ Schiller recognises that his theory implies criticism of Shakespeare as well as of the Greeks: for example, he criticises Iago and Lady Macbeth as regrettable elements in Shakespeare's tragic constructions (Op. cit., p. 8).
} 
the face of it, this reduces tragedy to an indirect path to the same configuration of thought and feeling as the contemplation of a raging storm might induce in us: awe at the power of nature combined with a judgement of our own absolute metaphysical invulnerability. It may then be asked how, on this view, tragedy can be thought to add anything to the experience of the sublime. In particular, why should suffering be the special focus of tragedy? Suffering functions in Schiller merely as the analogue in art of a raging storm in nature. This view implies that suffering has its place in tragedy in so far as it sharpens our apprehension of the boundary between freedom and nature, providing moral freedom with its 'other', and this reduction of suffering to a point d'appui for moral striving appears to reflect a misconception of the point of tragedy.

It should be said that Schiller does try to provide an essential role for suffering in tragedy and an account of how tragedy does more than recapitulate the sublime ${ }^{44}$ by claiming that tragic suffering provides the acutest possible occasion for self-affirmation - affirmation of oneself as transcending suffering through one's moral identity. But this is not convincing. Tragic protagonists do not characteristically terminate their course of experience in a vision of their own sublimity, as Schiller's account implies prima facie that they should. The reason for this, Schiller suggests, is that the effect of tragedy presupposes the thought of 'what should and can happen', the thought that 'one should disregard the [tragic] loss and that a duty exists to allow it no influence' on oneself. ${ }^{45}$ It can hardly be claimed, however, that this thought is standardly represented, even implicitly, within tragic works. If it is to come from anywhere, it must be supplied by the spectator. And this seems to reduce tragedy to a mere occasion for reflection: tragedy no longer provides an integrated experience, but a provocation, a cue for the spectator to reassure herself by entertaining thoughts that contradict those expressed within the work.

\footnotetext{
${ }^{44}$ In 'On the sublime (toward the further development of some Kantian ideas)' (1793) and 'On the pathetic' (1793), in Essays, ed. Hinderer and Dahlstrom.

45 'On the sublime', p. 43.
} 
This brief look at Schiller's Kantianised conception of tragedy allows us to grasp in more concrete terms the respect in which the world-characterisations of tragedy and morality conflict. The key lies in Nietzsche's recurrent theme of our attitude to suffering. What is most striking about Schiller's account is the way that it runs counter to what is surely the primary and weightiest element in tragedy, its representation of loss and suffering as ultimate realities, as facts with metaphysical depth. Even if we grant that some species of affirmation is an essential moment in tragedy, the moral self-affirmation and sublime transcendence of suffering that Schiller wishes to discover in tragedy does not accord with either the experience of the tragic protagonist or the spectator's response. Schiller's account entails the justifiability, in some sense, of tragic suffering: Schillerian tragedy enacts a kind of moral theodicy. ${ }^{46}$ To be sure, Schiller's view does not entail the grotesquery that tragic loss and suffering are themselves good - that what happens in tragedy is what ought to happen - or that they are nevertheless justified as means to moral ends: but it does entail that the point of tragedy lies in the final realisation that tragic loss and suffering are, in comparison with moral evil, of no true, ultimate import, and in that sense it affirms a total redemption. From the moral point of view, the ground that is lost by the tragic protagonist is, or can

${ }^{46}$ Schiller asserts that nature's contrapurposiveness counts for nothing in relation to moral purposiveness: sacrifice of life with moral intent is purposive to the highest degree ('Ueber den Grund des Vergnügens an tragischen Gegenständen’ (1792), in Schillers Werke: Nationalausgabe, vol. 20, Philosophische Schriften, Teil 1, ed. Lieselotte Blumenthal and Benno von Wiese (Weimar: Hermann Böhlaus Nachfolger, 1962), p. 138). That Schiller should take this view is less surprising when it is recalled that the moral theory which he applies to tragedy, namely Kant's, incorporates, via its moral theology, a theodicy. It is relevant to note J. B. Schneewind's suggestion that Kant's conception of the moral will developed from his attempt to construct a theodicy: see The Invention of Autonomy: A History of Modern Moral Philosophy (Cambridge: Cambridge University Press, 1998), pp. 492ff. 
be, made up: to the extent that moral goodness enters, tragic loss is offset. The Schillerian spectator is consequently invited to correct the tragic victim who believes that he has lost everything: ${ }^{47}$ this belief is, on Schiller's account, absolutely mistaken, because to the extent that the tragic victim has avoided moral evil, he has in reality lost nothing. ${ }^{48}$ So while it is true that the moral point of view need not be, in any ordinary sense, callous - it need not deny that loss and suffering of tragic proportion is truly unbearable, deeply regrettable and so forth - its appreciation of tragic loss and suffering is limited to according it only psychological reality: it does not stretch to allowing a sense in which tragic loss and suffering matter more than moral wrong, and when comparison is made of the two kinds of evil - moral evil and tragic loss - the moral point of view regards the former alone

${ }^{47}$ Schiller assigns this corrective role to the chorus, to which he attributes a reflective standpoint disjoint from the perspective of the tragic agent, in 'On the use of the chorus in tragedy' (1803), in Sidnell ed., Sources of Dramatic Theory, vol. 2: 'the chorus purifies the tragic poem by separating reflection from the action $[. .$.$] the chorus restores our freedom, which would otherwise be lost in the storm of emotion' (pp.$ 168-9).

${ }^{48}$ Martha Nussbaum makes a similar point (The Fragility of Goodness: Luck and Ethics in Greek Tragedy and Philosophy (Cambridge: Cambridge University Press, 1986), p. 386), but regards it as showing only the non-agreement of tragedy with a certain (Kantian) misconception of morality. Nussbaum argues (op. cit., pp. 380-91) for the view, which she attributes to Aristotle, that 'the value of tragic action is practical value' (p. 380): tragedy expresses the denial in Aristotle's ethics of the Platonic conception of the individual as enjoying 'rational self-sufficiency' with respect to the Good (p. 381); tragedy asserts the existence of a 'gap' between 'our goodness and our good living' (p. 382), i.e. the vulnerability of good character to luck. Historical questions aside, and whether or not such a conception of morality can (now) be regarded as coherent, Nussbaum's account seems not to make sense of tragic affirmation, and to make the negative moment in tragedy a shallower thing than it is experienced as being: the import of tragedy is reduced to the knowledge that the world can fail to be positively instrumental in relation to our aim of flourishing. 
as metaphysically deep. The moral point of view cannot, consequently, allow that tragedy is cognitive in the way that, on the Nietzschean view, we experience it as being: it cannot allow that tragedy expresses insight into the inner nature of the world in the sense that led Nietzsche to identify the Dionysiac at the heart of tragedy, and Arthur Schopenhauer to claim that tragedy shows 'the antagonism of the will with itself' ${ }^{49}$

The problem with the moral view, it should be stressed, is not that it moderates or mitigates, or that it reduces the impact of, tragic loss and suffering; the non-moral view too can hold that

${ }^{49}$ Arthur Schopenhauer, The World as Will and Representation (1819, 1844), 2 vols., trans. E. F. J. Payne (New York: Dover, 1969),

vol. I, pp. 252-4. There is more to be said against the moral view. First, it is a further consequence of Schiller's view that it alters our focus on tragic suffering, which it requires that we apprehend, not as an immediately given object, a pure brute fact, but under a description which reduces it to a mere exemplification - of our non-rational, 'sensible life'. This mediation seems contrary to experience. Second, it may be wondered if a moral-theodicean interpretation of tragedy does not entail either the ultimate inferiority of tragedy to comedy - a claim made by Schiller in 'On naive and sentimental poetry' (1800), in Essays, ed. Hinderer and Dahlstrom, p. 209 - or the blurring of the boundary between them - a feature of Hegel's view, noted by Stephen Houlgate ('Hegel and Nietzsche on tragedy', in Hegel, Nietzsche and the Criticism of Metaphysics (Cambridge: Cambridge University Press, 1986), pp. 203-4) - and if this does not comprise an objection to the interpretation. Third, it is to be noted how tragedy naturally provokes thoughts which employ moral concepts in a way which, from the perspective of morality, makes no sense - thoughts of the wrongness, unfairness, etc. of the world. Nietzsche, of course, would have us dispose of such judgements altogether, but that does not undermine the present point, which is that there are thoughts which we form inside the perspective of tragedy which the perspective of morality does not allow us to express. I will return to this in the second part of the paper. 
tempering mediation is necessary (Nietzsche holds that Dyonisiac insight requires Apolline mediation). Still less is the problem that the moral view insists on an affirmative moment, a counterweight. Again, Nietzsche, Yeats and others envisage a 'tragic joy' no less intense than tragic suffering. The problem lies instead with how, on the moral view, the mediation is achieved, and how the affirmation is related to the loss and suffering. The moral view reduces the impact of tragic loss and suffering by denying their significance and installs affirmation in the place of tragic loss. Comparison with the non-moral view brings this out. For Nietzsche it is precisely the Apolline mediator, not the Dyonisiac suffering, which is illusionistic, unreal. And tragic joy, unlike Schiller's moral self-affirmation, depends for its very existence on tragic loss and suffering: any denial of reality to the latter would entail a corresponding devaluation of tragic joy. The moral view, as it were, refuses to go into the loss and suffering in order to come out the other side: instead it retreats. This is not to say that tragic joy is genuinely possible: it is only to say that, if the loss and suffering is to be mitigated, and if this mitigation is to be achieved on terms set by the experience of tragedy, then it cannot take the form implied by the moral view.

Now it may be wondered if Schiller is a fair representative of the moral view of tragedy: only if the moral view entails the attitude towards tragic suffering expressed in Schiller's analysis of tragedy does this criticism of Schiller count against the moral view as such. The reason why it may be considered fair, is that, on any conception of morality intelligible to us, moral value is regarded as supreme (absolute, unconditional). Consequently morality must represent itself as able to make up for tragic loss and suffering. What sort of value would moral value be, if it could not do this? We conceive moral value as the form of objective value which has the closest possible relation to our essential selves. So we cannot say, in the perspective of morality, that a morally good man who has suffered tragic loss has truly lost everything - we must say, that he has at least not lost his moral integrity, and this we cannot regard as anything less than ultimate victory. For this reason loss and suffering cannot be acknowledged from the moral point of view to have the kind of unconditional 
and hence uncompensatable reality which they are represented as having in tragedy. Whence the optimism which Nietzsche repeatedly insists inheres in morality.

It should be noted that Kant himself, as may be seen from the earlier quotation, does not think that Schiller's view is viable: since Kant does not think that the 'evils' of nature can be weighed so lightly that they will not, without theological remedy, paralyse moral action. More clearsightedly than Schiller, Kant regards the world's evils as redeemable only on the conditions of a benevolent God and an afterlife. Thus it would be Kant's view that tragedy cannot be appropriated by the moral world-view in the way attempted by Schiller, and that tragedy's claim to say something true about the world should be denied. In other words, Kant would not recognise a category of tragic evil - loss and suffering as grasped in the perspective of tragedy - distinct from either moral or natural evil. ${ }^{50}$

The conflict with morality consists, therefore, in the opposition between the necessary tendency of morality to reshape the world in a manner that consolidates the reality of morality, and the implication of tragedy that such a moral theodicy is impossible. ${ }^{51}$ This conflict emerges from

${ }^{50}$ This is how Kant's extended struggle with the optimism question is eventually resolved. In the late essay 'On the miscarriage of all philosophical trials in theodicy' (1791) in Kant, Religion and Rational Theology, trans. and ed. Allen Wood and George di Giovanni (Cambridge: Cambridge University Press, 1996), Kant takes the position that the question of optimism or pessimism - in Nietzsche's terms, of the quality we assign to life - is resolved into a question of moral will. Adoption of the perspective of tragedy would block this solution.

${ }^{51}$ Note that it does not follow from what I have said that response to tragedy cannot legitimately take the moral form described by Schiller (or any other version of the moral view of tragedy): it can and should do so if the relevant moral convictions are allowed to determine responses to tragic works. Whether the convictions should do so - the normative status of this condition - is not a 
the 'negative' moment of tragedy - its representation of loss and suffering as the deepest facts about the world. Now I will argue that, if one agrees that there is affirmation too in tragedy, then its conflict with morality appears on a second front.

It is of course extremely hard to determine what tragic affirmation consists in. ${ }^{52}$ It is even denied by some that affirmation is a genuine element in tragedy at all. ${ }^{53}$ This consideration ought,

matter for a theory of tragedy to decide. My claim is only that the experience of tragedy does not, as the moral view claims, provide them with a warrant.

52 This question, note, is distinct from the question of why we take pleasure in tragedy, with which it is often and unfortunately confused. There are sound methodological reasons for giving low priority to the question of pleasure in consideration of tragedy: it encourages us to look for and to measure accounts of tragedy in terms of general puzzles in the philosophy of mind, the specificity of tragedy, and distracting us from the non-psychological question of the meaning of tragic affirmation (see Malcolm Budd, Values of Art: Pictures, Poetry and Music (London: Allen Lane, 1995), pp. 118-9, on the 'No Pleasure' theory). Though the broadly empiricist methodology of analytic aesthetics has allowed it to respect up to a point the distinctiveness of tragedy, its preoccupation with the hedonic problem has led it to conceive tragedy in Humean, naturalistic, psychological terms; see for example Flint Schier, 'The claims of tragedy: an essay in moral psychology and aesthetic theory', Philosophical Papers 18, 1989, 7-26, and 'Tragedy and the community of sentiment', in Peter Lamarque ed., Philosophy and Fiction (Aberdeen: Aberdeen University Press, 1983). Hegel excoriates the consideration of tragedy from 'the point of view of pleasant and unpleasant sensations' in his Lectures on the History of Philosophy (1840), vol. 3, Medieval and Modern Philosophy, trans. E. S. Haldane and Frances H. Simson (Lincoln: University of Nebraska Press, 1995), pp. 404-5.

${ }^{53}$ George Steiner, in 'Tragedy, pure and simple', in Peter Stern ed., Tragedy and the Tragic: Greek Theatre and Beyond (Oxford: Clarendon, 1996), denies the existence of tragic affirmation: his 
indeed, to be regarded as setting a constraint on any account of its nature, and as putting under suspicion any theory that implies that we ought to be able to articulate readily what it is about tragedy that elicits affirmation. The mark of tragic affirmation is precisely its diffuseness and lack of a clear propositional object, short of one identifying the tragic work as a whole. We are unable to give a fine-grained account of what the affirmation is grounded on, to say what it supervenes on, except, again, the work as a whole, or more particularly its negative moment. Hence, significantly, the characteristic employment of 'mood' words - joy, exultation, the sense of sublimity: states whose object, if any, is, approximately, 'the world at large' - to capture the tragic effect, in place of emotion words introducing 'that _' clauses, employment of which would commit us to 'why?' questions which in the context of tragedy cannot receive clear answers. To say, as one commentator has done, that we 'must be and we are glad that Juliet dies and glad that Lear is turned out into the storm,${ }^{54}$ may serve to convey the state of tragic exultation, but it is not literally true; the only

position is that, though tragedy 'implies positive values', they derive merely from the existence of the work of art, and that in so far as tragedy carries positive implications, it 'cheats' (p. 544). In Steiner's earlier The Death of Tragedy (London: Faber, 1961), ch. 1, by contrast, affirmation is regarded as essential to tragedy.

${ }^{54}$ Joseph Wood Krutch, 'The tragic fallacy', in The Modern Temper (New York: Harcourt, 1929), p. 125. (Yeats is equally provocative: 'In all the great tragedies, tragedy is a joy to the man who dies', Introduction to The Oxford Book of Modern Verse (Oxford: Clarendon, 1936), p. xxxiv.) Krutch rightly emphasises the autonomy of tragic affirmation, but his interpretation of it as presupposing a belief in human greatness, his comparison of the tragic spirit with a religious faith, and his consequent claim that we now are incapable of tragedy, are disputable. A different version of the thesis that tragedy belongs to the pre-modern world, based on different grounds, is expounded in Steiner, op. cit. For more balanced descriptions of tragic affirmation, see Bradley, 
objective happening that we may be straightforwardly glad of is that we as spectators have been exposed to the work.

The observation that tragic affirmation surrounds the tragic work in a form somewhat akin to that of a mood already counts against those versions of the moral view which imply that our affirmation is directed towards moral acts and dispositions represented in the work. Aside from the fact that many tragic works offer no such appropriate objects, the diffuseness of tragic affirmation makes it fundamentally different from any complex of moral judgements. ${ }^{55}$

What, then, are we affirming? What may be said in relative safety is that tragic affirmation is directed towards the course of experience and sequence of actions composing the narrative which defines the tragic protagonist, and that this object - the hero, his 'fate' - forms an undecomposable whole. In contrast with the way in which, in real life moral assessment, we separate out for purposes of judgement the different actions performed by a person and aspects of their character, our thought about the tragic victim is rather that their existence, their course of action and experience as a whole, the mere fact of their projection of themselves into the world, somehow constitutes a good it amounts to 'something', a phenomenon which is somehow, to put it at its weakest, worthwhile, to-be-willed, better than nothing.

Now in the present context the striking fact about this thought is that it is available for protagonists who are morally evil - for Macbeth as much as for the sweet prince. And this implies what ought to be evident anyway - that the value expressed in tragic affirmation is not morally conditional. We accord tragic value irrespective of moral failure or achievement: the phenomenon

Shakespearean Tragedy, pp. 269-74, and George Santayana, The Sense of Beauty: Being the Outline of Aesthetic Theory (1896) (New York: Dover, 1955), §§59-60.

55 This point is made by Goethe: tragedy induces 'a vague, uncertain mood', and 'cannot affect morality' ('On interpreting Aristotle's Poetics', in Sidnell ed., Sources of Dramatic Theory, vol. 2, pp. 151-2). 
exhibited in tragedy is valued with indifference to moral goodness; morally goodness does not increase it, and moral evil does not diminish it. This is why, in the moment of anagnorisis, the tragic protagonist who is morally self-destroyed can nevertheless find a consolatory source of selfaffirmation: he discovers himself to be beyond morality, to possess a kind of value from which morality cannot alienate him. Macbeth discovers that he is not 'annulled' by his evil: there is in him a dimension of value which is immune to moral criticism, which morality cannot subtract from. Tragic value thus eclipses or overshadows moral value, rendering the negative and affirmative moments of tragedy symmetrical: tragic value, like tragic loss and suffering, represents itself as possessing greater depth than moral value.

Upholders of the moral view of tragedy who have confronted the challenge posed by Macbeth have suggested that the object of tragic affirmation is moral potentiality - the power of free choice which constitutes the capacity for morality (in Kantian terms, Willkür, the capacity for Wille), or the virtues of resilience and determination which could have been put in the service of moral ends and which would then have delivered extraordinary results. ${ }^{56}$ But this proposal does not

${ }^{56}$ Schiller, 'On the pathetic', pp. 61, 68. Bradley says that the presence of evil characters in modern tragedy is explained by the independence of the interest in their characterisation from their serving as Hegelian emblems for aspects of ethical substance: they are allowed 'some peculiar charm or some commanding superiority' ('Hegel's theory of tragedy', in Oxford Lectures on Poetry (London: Macmillan, 1909), p. 78). Whether or not this interest explains the greater individualisation of characters in modern tragedy, it does not explain their characterisation as specifically evil. Consider Bradley's account of Macbeth, which he rightly identifies as apparently 'a most unfavourable instance' for his account of tragedy (p. 87). Bradley locates the tragedy in the loss of what there is in the tragic hero which is admirable, his virtues of extreme courage and determination, 'forces [of personality] on which you place a spiritual value' (p. 88): these are 'in themselves, good, and gloriously good'. But if this were all, then our thought would be simply of the shame that 
provide convincing support for the moral view of tragedy. In the first place it seems clear that tragic affirmation is unaccompanied by any thought of what Macbeth might have done - its full object is contained in his actual narrative. Second, while it is coherent to suppose that the bearer of tragic value must be something that has moral potential, and so not an animal, infant or somnambulist, it does not appear coherent to suppose that the object of tragic affirmation is valued in the same respect both intrinsically and by virtue of its potential for moral actualisation; not, at any rate, when its moral and non-moral actualisations are in fact valued equally by us.

This point is recognised, in inverted form, in Johnson's famous censure of Shakespeare: 'He sacrifices virtue to convenience, and is so much more careful to please than to instruct, that he seems to write without any moral purpose [...] he makes no just distribution of good or evil, nor is always careful to show in the virtuous a disapprobation of the wicked; he carries his persons indifferently through right and wrong, and at the close dismisses them without further care. ${ }^{57}$ The phrase - 'carries his persons indifferently through right and wrong' - captures exactly the nonmoral dynamic which is the key to tragic affirmation.

Tragic value is, evidently, mysterious, and perhaps there is no more to be done with it philosophically than to give it an appropriately suggestive name - the 'Dyonisiac'. In the second part of the paper I will try to say more about it, but the important point is that tragic value should be recognised for what it is, and not falsely assimilated to some other, more familiar and rational species of value, such as the moral. ${ }^{58}$

Macbeth's qualities were not harnessed to moral ends; our attitude would be merely ambivalent, a compound of approbation and disapprobation; from which would issue regret, but not the affirmation that we make with respect to Macbeth.

57 'Preface to Shakespeare' (1765), in Enright and de Chickera eds., English Critical Texts, p. 140.

${ }^{58} \mathrm{~A}$ further issue to be noted is whether the form of tragedy as such dictates anything about the relative weights of its negative and affirmative moments - whether tragic value is necessarily 
It should be pointed out that it does not follow from what has just been said - though talk of a conflict of values may seem to suggest it - that the conflict between tragic and moral value can assume a practical form. If tragic consciousness were the consciousness of an 'ought' with the same categorical force as the moral ought, but pointing in a different direction, then we would be faced with the choice, Tragedy or morality? But just as tragic affirmation is inherently indeterminate, so there is no determinate practical upshot of tragedy. There could be a practical choice between moral and tragic value only if it were possible to translate the experience of tragedy into practical terms. Nietzsche may have thought this possible, though even for him it would seem to require the mediation of an entire culture. ${ }^{59}$ There is, however, no ground for thinking that reasons for action can be extracted from the experience of tragedy. The perspective of tragedy is of course necessarily connected with the practical perspective - tragedy is the contemplation of a doing, the object of practical consciousness - but it does not apprehend its object in a practical mode. Like aesthetic consciousness in general, tragedy provides a point of view apart from theoretical and practical consciousness: we arrive at the perspective of tragedy by, as it were, adopting the practical perspective and then exporting its object, viz. life presented as a domain for practical reason, to a

proportional to or even, as Nietzsche presumably contends, outweighs the loss and suffering. It is however hard to see why the proportion should be fixed.

${ }^{59}$ To the extent that Nietzsche believes in a line of progression running from the experience of tragic art to a tragic form of life - and perhaps to values of heroism and nobility - this is a strand in his thought which belongs alongside his famously puzzling and problematic notion of 'aesthetic justification'; see Volker Gerhardt, ‘Artisten-Metaphysik', in Pathos und Distanz (Stuttgart: Reclam, 1988). 
contemplative context. ${ }^{60}$ So though tragedy may allow us, as spectators, to 'see' beyond morality, it does not take us, as agents, beyond morality. This is part of the reason why we need to repeat the experience: the perspective opened up by tragedy is one that we, as being with lives to lead, cannot occupy; tragic knowledge of what is valuable about life cannot be preserved intact within life itself. This is not to say that it is impossible to support an ethic by an appeal to tragic experience - only that there is no direct transposition of the experience of tragedy into a conception of a way of living; the experience of tragedy does not itself provide sufficient grounds for an ethic of, for example, personal heroism. ${ }^{61}$

It should be observed that the kind of conflict of tragedy and morality which I have described fits exactly the bill drawn up earlier, for it does not imply that tragedy valorises immorality. The conflict of tragedy with morality which I have described is nothing like the familiar conflict of the proponent of morality with the egoist, amoralist or moral skeptic. It is much subtler, and the subtlety of the conflict is also the reason why it eludes us. In the first place, because the world-characterisation which moral consciousness projects and which tragedy contradicts, is related only obliquely to the moral thinking of agents engaged in the worldly task of practical judgement it is a necessary accompaniment which reveals itself when morality is allowed to fill out philosophical space, a kind of transcendental presupposition rather than an element with a direct role in practical reasoning - it is no puzzle that this aspect of the conflict of tragedy with morality

${ }^{60}$ This, I think, is how Schiller's claim that 'the writer of tragedies always treats his subject matter practically, while the writer of comedies always treats his theoretically' should be understood ('On naive and sentimental poetry', p. 208).

${ }^{61}$ Schelling warns against turning tragic art into a 'system of action': Philosophical Letters on Dogmatism and Criticism (1795), in The Unconditional in Human Knowledge: Four Early Essays (1794-1796), trans. Fritz Marti (Cranbury, New Jersey: Associated University Presses, 1980), p. 194. 
should remain unperceived by the spectator; at most it is sensed indistinctly, without being explicitly formulated. Second, we are subject to a kind of trick of perspectives. When we are directly exposed to the insight expressed in tragedy - because we then occupy an aesthetic perspective that suspends our practical orientation - we do not become reflectively aware of how we have moved away the perspective of morality. And when we reflect on tragedy at a remove from the original experience, restored to the perspective of morality, we then reinterpret our experience as morality requires us to do - in morally congenial terms, thereby arriving at a moral interpretation of tragic suffering and affirmation. If the insight gained in tragedy could survive outside the original aesthetic context, then this moral appropriation of tragedy would be blocked; but this is impossible, because, as said earlier, a state of insight that concerns life as a totality cannot be maintained within the conditioned, partial perspective of life itself. For this reason, what we experience in tragedy remains partially incommunicable to ourselves.

At this point in the discussion it is appropriate to say something brief about Hegel's theory of tragedy. Earlier it was argued that the conflict of tragedy with morality cannot be eliminated simply by shifting to a different conception of morality, due to the way in which the significance of morality refuses to allow itself to be shrunk. One might, however, expect this difficulty to be overcome in Hegel, who, after all, both attached exceptional philosophical significance to Greek tragedy and developed a critique of Kantian moral theory, all the while recognising that the modern discovery of individual moral autonomy cannot be undone. ${ }^{62}$

At one level, this is so: Hegel succeeds with brilliance in fashioning a super-conception in which tragedy becomes an essential moment of morality itself. The cost, however, on the side of tragedy, is something not far from that which it bears on Schiller's Kantian theory.

In a limited sense, Hegel agrees, with Nietzsche, that tragedy is trans-moral: Hegel accepts that the relation of morality to tragedy is too oblique to be captured in the formulas of neo-

\footnotetext{
62 This is disputed; see, however, Pippin, 'Hegel's moral rationalism', in Idealism as Modernism.
} 
classicism, that there is a kind of conflict with morality in tragedy, and that tragic consciousness cannot be identified with any particular ethical point of view; any moral standpoint (short of the universal standpoint of Hegel's own Philosophy of Right) can be examined in the light of and overthrown by tragic consciousness. Nevertheless, on Hegel's view there is an ultimate (moreover, contentful, not merely formal or transcendent) attunement and coincidence of moral and tragic consciousness. Tragedy, on Hegel's account, has its source ultimately in objective, not subjective spirit, in ethical substance rather than individual psychology. It represents in the final analysis not the bearing of the ethical on the individual, but conflictual relations between the largest forms of the ethical, as it particularises itself in human life. ${ }^{63}$ Tragedy thus transcends the moral perspective of the individual, but not the moral as such: it is constituted by oppositions between ethical conceptions, not by an opposition of the moral to some other species of value.

Though some tragic works appear to conform to Hegel's pattern, many do not. Modern, 'subjective' tragedy, where individual motivation is of central interest, is regarded by Hegel as inferior to 'objective', classical tragedy. This is a major limitation. Even if Hegel were right about the objective ethical meaning of ancient tragedy, and its distinctness from a modern interest in individual subjectivity, it is not an option for us to follow Hegel in regarding this interest as a distraction, an inessential deviation. ${ }^{64}$ The deeper objection to Hegel has to do, therefore, not with

${ }^{63}$ See Hegel, Aesthetics: Lectures on Fine Art (1835), 2 vols., trans. T. M. Knox (Oxford: Clarendon, 1975), vol. 2, pp. 1192-1237.

${ }^{64}$ Bradley, 'Hegel's theory of tragedy', provides an excellent critique. While praising Hegel's theory of tragedy, Bradley asserts the need to go beyond Hegel, and on pp. 86-7 Bradley proposes an emendation to Hegel's theory which, he claims, would overcome its limitation to ancient tragedy. Its implication, however, is to loosen the relation of tragedy to morality in a way that Hegel would be bound to reject. Bradley uses the notion of 'spiritual waste' - 'self-division and self-waste of spirit' - as the key to tragedy. He asks why the conflict of anything that has 'sufficient value' 
the exegetical fit and scope of his theory, but with his account of the central focus of our interest in tragedy. It might be true that all tragic protagonists exemplify conflicting aspects of ethical substance, but it would not follow that this is what tragedy revolves around, and unless what was said earlier about an antagonism with the world being at the heart of tragedy is mistaken, it cannot be: if Hegel were correct, then opposition of human being to its non-human Other would be either absent from or peripheral to tragedy; the line between self and world would be dissolved in favour of lines of distinction between different ethical entities or intersubjective configurations. It might be suggested that, on Hegel's interpretation, the 'world' to which in tragedy human beings are represented as opposed just is ethical substance. But even then, what interests us in tragedy is the manner in which the individual confronts this semi-alien power, not the question of its internal rationality. The point stands that tragedy is constituted by an experience modelled on the traditional, unmediated opposition of subject and object, not by an experience of internal relations within the (ethical) world.

For the same reason, Hegel does not demonstrate the attunement of tragic and moral consciousness, if this is supposed to belong to the experience of tragedy, and not to be the result of subsequent, extraneous reflection on the experience. In order to know that, as Hegel's account implies, tragic loss and suffering is not in vain and can be recuperated, we need to refer to Hegel's

should not 'affect us tragically', and answers that it does. Thus, he concludes, 'any spiritual conflict involving spiritual waste is tragic'. But if we allow that tragedy is concerned with 'spirit' Bradley's comprehensive term for human value - and that spirit extends further than morality, then we must also allow that the sphere of tragedy is broader than that of the ethical, and that tragic value is not identical with moral value. Hegel was, therefore, right to hold the theory of tragedy at the level of ethical conflict, in the sense that such a restriction is necessary if tragedy is to be kept essentially aligned with morality. Bradley's treatment thus provides confirmation of the conclusion regarding Hegel that I go on to argue for. 
speculative metaphysics; but the monism of Reason, whether or not it can be teased dialectically out of ordinary natural consciousness, is not explicit in it, and in any case, according to Hegel himself, the speculative standpoint cannot be presented within a work of art.

Thus in the context of tragedy, if in no other, there appears to be reason for thinking that natural consciousness resists the upward movement towards the standpoint of speculative philosophy: all that Hegel may justifiably claim, therefore, is that his account describes the revisionary interpretation of tragedy which the speculative standpoint demands. If these criticisms, though brief, are accurate, then the case of Hegel serves to reconfirm the Nietzschean conclusion: the reconciliation of tragedy and morality that Hegel seeks is blocked by his commitment to preserving the rationalistic, Kantian aspect of morality. ${ }^{65}$

${ }^{65}$ Houlgate, in Hegel, Nietzsche and the Criticism of Metaphysics, ch. 8, makes fierce criticisms of Nietzsche and shows Hegel's view to be more nuanced and defensible than is generally thought (even by Bradley). His argument, however, tends to presuppose the Hegelian theses that Nietzsche's outlook may be relegated to a historically earlier, 'heroic' shape of consciousness, and that transcendence of tragic suffering is genuinely possible. My criticism of Hegel is corroborated by the omission in Houlgate's account of Hegel's view of any account of an opposition of man and world, in favour of an emphasis on intersubjective relations. There are also doubts to be entertained regarding the coherence of the attributions of responsibility which Houlgate shows to be required by Hegel's theory (Nietzsche's account, by contrast, makes questions of responsibility ultimately inessential to tragedy). Robert R. Williams, Recognition: Fichte and Hegel on the Other (Albany: State University of New York Press, 1998), ch. 10, provides a rich and complex account of the theme of tragedy in Hegel. Williams denies that Hegel's philosophy excludes tragedy - the view that 'Hegel comes to interpret tragedy from comic premises, i.e. from the presupposition of a reconciliation which lies beyond tragedy' - but concedes that in order for it to be held to incorporate 
Finally, I wish to return to the question of reconciling tragedy and morality. I claimed earlier that logically this could be achieved, but only by stepping outside the experience of tragic art so as to view the perspective of tragedy as merely partial, to do which, I suggested, is to break faith with the experience of tragedy, to fail to give it its due. ${ }^{66}$

This last point is, however, in need of refinement. The need of philosophy to achieve a 'super-perspective' which comprehends and reconciles the conflicting perspectives of morality and tragedy is, of course, recognised by Schiller and Hegel: it is exactly what their accounts of tragedy aim at. The problem with their accounts, it should now be said, is not that they aim at tragedy's reconciliation with morality, but that they do so on terms set by morality: it is tragedy which is required to surrender its claim to be a total representation. And to the extent that this 'reconciliation' is in truth a victory for morality, it is appropriate, I have suggested, to revert to the Nietzschean view that tragedy and morality conflict.

But suppose we continue to think it important to defuse the conflict of tragedy with morality. If we harbour suspicions about morality, such as those of Nietzsche post-Birth of Tragedy, then we could resolve the conflict by showing that moral value is illusory. But if we do not share Nietzsche's view of the desirability of releasing ourselves from morality's practical sovereignty, ${ }^{67}$

tragedy, it 'must be conceded that tragic conflict for Hegel is not absolutely irreconcilable' (pp. 235-6).

${ }^{66}$ As a kind of partial confirmation of this thesis, it may be considered how philosophers, other than Nietzsche, who have articulated unmistakably tragic visions of the human condition have either exhibited a seeming indifference to ethical theory (Heidegger), or encountered special difficulty in moving from metaphysics to morality (Sartre), or constructed a moral theory with an exceptionally problematic foundation (Schopenhauer).

${ }^{67}$ Nietzsche's antagonism towards morality, whatever stimulus it may have received from his estimate of the experience of tragedy, has of course other sources. 
then what remains conceivable is a 'super'-perspective that goes the other way round from Schiller and Hegel, i.e. that comprehends morality on terms set by tragedy. What would this amount to? It would involve claiming that in reality, though not in our apprehension, the object of tragic affirmation supplies the ground of moral value, while denying that the value of tragic experience lies in its moral purposiveness, and relinquishing the claim that moral value is metaphysically supreme. But it would not, for all that, undermine the rationality of morality: moral requirements would remain categorical and our reasons for action would be left unaffected. ${ }^{68}$ To that extent it would amount to a genuine reconciliation. At the same time, a genuine metaphysical demotion of morality would be involved, as can be seen by comparing the place of moral value in the tragic vision, with its place in the Judaeo-Christian theistic vision, where moral value is what takes us closest to the infinite being which constitutes absolute reality. ${ }^{69}$

Nietzsche would reject this reconciliation, not only because of his interest in pitting tragedy against morality by giving it practical force, but also on the grounds that it requires an other-worldly commitment. But this is, again, another matter. All that should be concluded here is that the existence of a conflict of tragedy and morality at the first level of reflection, which is all that I have

\footnotetext{
${ }^{68}$ Indeed, since awareness of a trans-moral form of value and the consequent limitation on morality in no way implies moral nihilism, it is wholly compatible with tragic affirmation that there should be some sense in which, as A. D. Nuttall puts it, "The words "good" and "evil"' mean not less but more to one who has just watched King Lear' (Why Does Tragedy Give Pleasure? (Oxford:
} Clarendon, 1996), p. 105).

${ }^{69}$ Since not all religions bind divinity with morality in the manner of Judaeo-Christian theism, religion as such is not in conflict with tragedy - as The Birth of Tragedy emphasises. Religious systems such as Zoroastrianism and Gnosticism contain elements which cohere with the perspective of tragedy. 
been trying to show, does not entail the impossibility of their reconciliation at a higher, speculative philosophical level.

The route from tragedy to morality hypothesised earlier - viz., that tragedy wakens us to morality's demands by sharpening our sense of the fragility of goodness - is therefore superficial and misleading. Though tragedy may, as a matter of psychological fact, often or always shock us into abiding by the moral law, at a deeper level the lesson of tragedy is not the importance of morality. Tragedy offers a total perspective on the world which does not accord with the way in which moral reflection conceives it: moral consciousness regards human subjectivity as at home in the world in a way that tragedy says it is not, and it cancels the human antagonism with the world which tragedy presupposes. Furthermore, tragedy contests the supremacy of morality by intimating a more fundamental kind of value which is indifferent to moral concerns and which cannot be brought into coherent relation with moral value without ascending to a speculative philosophical level. Next I will offer an account of the nature of tragedy which, if acceptable, makes these conclusions more plausible.

\section{II}

There are some uses that we make of the concept of life which show us to have in mind a notion which is at once highly indeterminate and extremely important. We speak of a life as fulfilled or unfulfilled, devoted to such-and-such, wasted, sacrificed, bearable or unbearable, and so forth - of life not as a state or process but as a kind of unique, singular object towards which we are each intentionally related. ${ }^{70}$ Clearly the thought here is not of an extent of time defined by any sort of natural process, as in the life-cycle of an organism. Nor is it strictly identical with the idea of a personal narrative: one's life is the object which is defined by one's biography, in the way that a

${ }^{70}$ Gerhardt, 'Nietzsches ästhetische Revolution', in Pathos und Distanz, p. 21. 
substance is related to a mode. Nor, again, is a person's life, to which she is related possessively, identical with the person herself. Life in the relevant sense is essentially personal, temporal, and linked with, as having or lacking, value. But the concept is neither moral nor psychological. We might, therefore, think of it as a transcendental concept: it has no empirical referent, specifies a form which awaits empirical content, and it makes its object possible (only a being that can think of itself as having a life can have a life, and any being that has the concept of having a life has a life). ${ }^{71}$

Now we might think of tragedy as the form of art which provides us with the most direct and pure experience of this form which is available to us. That is to say: the object that we apprehend in tragedy is essentially, when abstraction is made of the specific content through which tragic representation allows us to become acquainted with it, the form of human life in general. ${ }^{72}$

The hypothesis is metaphysical, in the sense that it attributes a meaning to tragedy that is not psychological and that goes beyond anything that is directly warranted by the manifest, directly observable features of tragic works. ${ }^{73}$ With appropriate elaboration, it can be rendered plausible and

${ }^{71}$ Friedrich Schlegel, 'Athenaeum fragments', in Philosophical Fragments, trans. Peter Firchow (Minneapolis: University of Minneapolis Press, 1991), 285: 'A transcendental perspective on this life still awaits us. Only then will it become really meaningful for us.'

72 This idea derives loosely from Georg Lukács, 'The metaphysics of tragedy', in Soul and Form, trans. Anna Bostock (London: Merlin, 1974). The concept of the form of human life is, note, not the same as that of mere temporal or narrative form, nor of the typical character of human life. To say that tragedy presents the form of human life is also distinct from, though it is closer to, Schopenhauer's claim that 'The life of every individual, viewed as a whole and in general, and when only its most significant features are emphasized, is really a tragedy' (The World as Will and Representation, vol. I, p. 322).

${ }^{73}$ For a clear example of an interpretation of tragedy that follows an opposite, empiricist methodology, seeking to explain the value of tragedy only by reference to manifest features of tragic 
attractive. It has the initial virtue of doing justice to the preeminence accorded tragedy as a form of art and to our sense that the concept of tragedy cuts in an especially deep way across the distinction of art from life. The form of human life, we may suppose, is apprehended intuitively, not discursively, in tragedy. ${ }^{74}$ Other forms of art and other (historical, biographical, autobiographical) narrative representations of human experience do not provide us with this intuition, because they do not rise to the same unconditional, all-comprehending level. Tragedy achieves this by representing an action in which everything - the totality of what is at issue and matters for a human being - is at stake, and all of the content with which a human life may be filled - the substantive goods with which a person may identify - is stripped away. ${ }^{75}$ This totalisation and reduction both figures in the

works, see Budd, Values of Art, pp. 119-22. Budd identifies the central value of tragedy with the 'insight' it provides. The question raised - which indicates the general difficulty for empiricist approaches to tragedy - is how the content of this insight is to be conceived. The tendency of empiricist approaches is however to put in doubt the supposition that a theory of tragedy, in the strong, explanatory rather than descriptive sense, is needed; see Budd, ibid. ('tragedy lacks a precise essence'), and C. S. Lewis, 'Tragic ends', Encounter 18, 1962, 97-101 ('tragedy, taken as a common essence of which all “tragedies"' are instances, is a phantom concept', p. 98). Empiricist doubts about the existence of an 'essence' of tragedy should be distinguished from the overtaking of the category of tragedy found in Croce and Collingwood's aesthetics (see n89 below).

${ }^{74}$ The idea of an intuition of human life is found in Martin Heidegger's book on Kant (Kant and the Problem of Metaphysics (1929), 4th edn., trans. Richard Taft (Bloomington: Indiana University Press, 1990), §22); Being and Time (Division Two) may be regarded as an attempt to articulate discursively the intuition.

${ }^{75}$ As Schelling puts it: 'The tragic hero must, in whatever respect, possess an absoluteness of character such that external elements are merely material for him' (The Philosophy of Art (1804-5), ed. and trans. Douglas W. Stott (Minneapolis: University of Minneapolis Press, 1989), p. 252). 
perspective of the protagonist (tragedy cannot be suffered unwittingly; Aristotle's requirement of anagnorisis) and marks the manner in which the hero's experience is presented to us by the work. For example, through elevated social status and greatness of spirit: the concerns and goods of a king, and of one whose grasp of life and other endowments are exceptional, being the greatest possible for a human being. Other, non-tragic narrative representations of human experience do not press the same claim on us: however comprehensive they may be at the level of content, they do not pretend to capture a metaphysical whole, and so do not make the transition from content to pure form.

Though tragedy represents human life as a totality, it also represents it as finite. Also included therefore in the tragic intuition is therefore the indeterminately conceived extra-human world in general, as that to which human life is opposed. If then we attempt to express the intuition by means of a visual analogy - in Kantian terms, if we search for an 'aesthetic idea' to render in sensible terms the intuition of a human life, to symbolise it - it may be compared with the appearance of a human figure against a featureless ground, or more exactly, with the temporal process of the differentiation of the figure from its ground. What effects this differentiation within a tragic representation is precisely the loss and suffering, and the striving, of the protagonist. Because the intuition of form is delivered through this medium, we do not think of its object, human life, as detachable from this dimension of (intensified and interfused) passivity and activity. Human life as experienced in tragedy is consequently a phenomenon to which suffering and loss are essential. The affirmation in tragedy may be thought of, similarly, as integral to the intuition, such that in tragic experience our awareness of the object, the form of human life, and our apprehension of it as having value, are experientially indistinguishable.

The implications of this account are such as would explain the distinctive features of tragic experience noted earlier. It explains the spontaneity, and the reasonless, mood-like character of tragic affirmation - the way in which it is part of the thought of tragic affirmation that that there is no question of its being supplied with any reason. The intuitive character of our apprehension 
explains why there can be no question of a discursive proof (defence, explanation) of tragic value (any more than there can of our existence, or its temporal character). Also explained is why tragic value can attach to evil characters: our consciousness of Macbeth's evil, his moral nothingness, brings into focus another, non-moral dimension of him; as he is morally stripped, something else shines through his moral negativity. Furthermore, the notion which is found in many versions of the moral view of tragedy, that tragedy gives us an intensified, affirmative experience of certain, virtuous qualities of mind or character - resoluteness, perseverance, determination, the capacity to rise above adversity, etc. - can be divorced from the moral view. ${ }^{76}$ To the extent that these qualities contribute to a specifically tragic experience, they are valued not qua moral virtues but qua clear and distinct manifestations of the form of human life. This is intuitively correct: qualities of this energetic sort affect us without any thought of their moral connection (which is in any case tenuous), simply on account of their elemental active character, the manner in which they evoke a sense of human personality as pure dynamism, self-projection. To this extent there is, then, an element of 'rightness', of purposiveness fulfilled, in the tragic development; but it is not what the moral view of tragedy takes it to be, namely a matter of things going according to moral plan.

Just as the hypothesis implies that these features, of apodicticity and openness to evil, are necessarily present in the experience of tragedy, so it also implies that certain other matters are, appropriately, left open. It leaves undecided whether the negative moment in tragedy, the stripping away of content from life, is merely a condition for us to apprehend its form and its value, or whether it is a condition of the form's having value: in other words, it leaves undecided whether any soterial character can be attributed to suffering itself. It also leaves undetermined how tragic value is to be conceived in subsequent reflection. On the one hand, there is pressure, deriving from the structural opposition in tragedy of human being to the extra-human world, to think of tragic value as emanating directly from human existence, as if it were its own source. Pursuing this

${ }^{76}$ See n53 above, and Budd, Values of Art, p. 122. 
idealistic, humanistic line, tragic affirmation might be identified with a primordial, spontaneous act of conferring value on oneself. This will be the natural way of conceiving tragic value if human being itself is conceived idealistically (if the human figure is conceived as differentiating itself spontaneously from its background). But the experience of tragedy does not force on us this conception of autonomous value-creation. All that tragedy represents, strictly, is the human figure's possession of value irrespective of its relation to any life-content; the tragic work is silent on the score of where the value stems from. We are therefore left free to take a realistic view of tragic value, i.e. to think that tragic value is not simply self-bestowed. Nothing in the bare experience of tragedy determines us either way. The one possibility that the hypothesis does rule out is that tragic value is moral value: if the form of human life as such has value, then it cannot be for a moral reason.

The hypothesis that the experience of tragedy consists in an intuition of form does not therefore, though initially its abstractness may seem to count against it, contradict anything in our pre-theoretical conception of tragedy: all of the features of content that are held to characterise tragedy - unity and seriousness of action, social distinction of the protagonist, loss and suffering due to causes in which activity and passivity are entwined, self-recognition and death of the hero, affirmation - are intelligibly related to the hypothesised apprehension of form. In addition, the hypothesis provides an account of the essence of tragedy which accords it the right degree of indeterminacy. Indeterminacy is needed in two respects: as an internal feature of the experience of tragedy itself, as indicated earlier, and in order to account for the plasticity of tragedy, its ability to assume an endless variety of novel artistic forms and to lend itself to a multitude of different philosophical interpretations.

In pursuit of this last point, I now want to indicate how the account of tragedy given here can be seen to be reflected in selected writings on tragedy other than The Birth of Tragedy.

First, returning to Schiller, it is significant that in a essay written slightly later from the one drawn on previously, Schiller states his view in a way that loosens the connection of tragedy with 
morality. ${ }^{77}$ Schiller is here provoked by the fact that our affective responses to figures in tragedy do not follow obvious moral contours. In an attempt to reharmonise apparently morally deviant responses to tragedy with moral interest, Schiller employs two distinctions: between aesthetic and moral judgement, and between moral capability and actual moral conduct. This allows him to claim that positive affective responses to figures whose actual conduct is not moral may be interpreted as issuing from aesthetic judgement the object of which is moral capability. This leads Schiller to say that 'in aesthetic judgements we are interested, not in morality itself, but simply in freedom', that the focus of tragic interest is 'a principle transcending the senses in a human being' rather than morality as such, and that what matters for tragedy is that the individual should manifest only the 'vocation' for morality, not an actual moral will. ${ }^{78}$ Our response to tragedy Schiller here describes as a 'lofty feeling of freedom'. ${ }^{79}$

The effect of this shift, however, is on the face of it to make tragedy autonomous from morality. Since the 'aesthetic' modality of tragic response is remote from any formalism, tragic response having been accorded its own complex, non-sensory judgemental target, viz. freedom or supranatural being, and since tragic response sustains itself independently of and on many occasions goes against the grain of moral response, the onus of showing that the 'freedom' valorised in tragedy is essentially moral now lies once again with Schiller. He may try to meet the challenge by appeal to the Kantian argument for the identity of a free will with a moral will. ${ }^{80}$ But he will

\footnotetext{
77 'On the pathetic'. ${ }^{78}$ Op. cit., pp. 68, 53, 61 .

${ }^{79}$ Op. cit., p. 58. See also 'On naive and sentimental poetry', p. 208: 'the aim of tragedy is to help restore freedom of mind by aesthetic means'.

${ }^{80}$ Schiller rejects the dissociation of freedom from morality as a 'false idealism' ('On naive and sentimental poetry', pp. 259-60), and charges that the 'visionary' who locates his freedom in being released from moral constraints must 'end in complete annihilation'. The Nietzschean retort would
} 
nevertheless have made admission that, at the first level of reflection on the experience of tragedy, the link with morality is absent. Schiller's experience of the sublime, freed from its Kantian interpretation, is only a hair's breadth from Nietzsche's experience of the Dionysiac and the Apolline in fusion.

A closely parallel case is that of Shelley. A Defence of Poetry, though it presents itself as propounding a solidly moral conception of art, is far from unambiguous on this score. Shelley considers the objection to epic and dramatic poetry that its characters are frequently 'remote from moral perfection', and responds by saying: 'a poet considers the vices of his contemporaries as a temporary dress in which his creations must be arrayed, and which cover without concealing the eternal proportions of their beauty' ${ }^{81}$ Whether this answers the charge and implies a moral view of tragedy, depends however on whether the inner beauty that Shelley refers to is moral. By implication, Shelley must presume it to be, but as in the case of Schiller, it is open to doubt whether he has grounds for the moral characterisation: certainly they are not provided by his neo-platonist borrowings, ${ }^{82}$ and Shelley's forthright repudiation of didacticism makes the question especially pertinent. $^{83}$

be, of course, that this merely reflects the limit of the moral perspective - what Schiller perceives as 'complete annihilation' is the point of tragic affirmation. In any case, by acknowledging the possibility of 'false idealism', Schiller concedes that freedom can at least appear distinct from morality, and the systematic expansion in German idealism of the concept of freedom beyond its Kantian moral meaning shows that, if this appearance is mistaken, the mistake is at least not a shallow one.

${ }^{81}$ A Defence of Poetry, pp. 423-4.

${ }^{82}$ On which, see M. H. Abrams' comments in The Mirror and the Lamp: Romantic Theory and the Critical Tradition (Oxford: Oxford University Press, 1971), pp. 127ff. What further renders Shelley's claim to have achieved a moral defence of poetry insecure is his conception of the content 
Shelley's choice of terms, and other of his claims, suggest instead a more Nietzschean view. Epic and dramatic poetry shows, he says, 'beauty of the internal nature', 'naked truth and splendour', while moral attributes are reduced to outward shape and 'costume'; ${ }^{84}$ Athenian tragedy represents 'that ideal perfection and energy which everyone feels to be the internal type of all that he loves, admires, and would become'. ${ }^{85}$ And, Shelley continues, strikingly: 'even crime is disarmed of half its horror and all its contagion' in tragedy; 'error is thus divested of its willfulness; men can no longer cherish it as the creation of their choice'. It is hard not to regard Shelley as manifesting here a clear awareness of how tragic affirmation is basically distinct from, and experienced as superceding, the moral perspective; behind his intended distinction of universal from merely local morality appears to lie a contrast of non-moral with moral value.

Here again, then, it is as if a different understanding of tragedy has broken through. The moral casing is in fact frailer in Shelley than in Schiller: Shelley's famous judgement that 'Milton's Devil as a moral being is as far superior to his God ${ }^{86}$ really means, one is tempted to say: Milton's

of poetry as accessible only from inside poetic experience; this, as astutely noted by Wimsatt and Brooks (Literary Criticism, pp. 422-3), is what deeply distances his defence from Sidney's, which it otherwise echoes.

${ }^{83}$ See op. cit., p. 428, regarding tragedy reduced to 'a weak attempt to teach certain doctrines, which the writer considers as moral truths'. See also William Blake, 'On Homer's poetry' (c. 1818): 'Aristotle says Characters are either Good or Bad: now Goodness or Badness has nothing to do with Character [...] Unity \& Morality are secondary considerations, \& belong to Philosophy \& not to Poetry' (Poems and Prophecies, ed. Max Plowman (Dent: Everyman, 1976), p. 285).

${ }^{84}$ A Defence of Poetry, p. 424.

${ }^{85}$ Op. cit., p. 428.

${ }^{86}$ Op. cit., p. 437. 
Devil is as a tragic being far superior to his God, a merely moral being. ${ }^{87}$ This is not, of course, to say that either Schiller or Shelley are really Nietzscheans, but simply to indicate the pre-history, and to that extent the non-eccentricity, of the view expressed in The Birth of Tragedy.

As well as revealing the non-moral aspect of the romantic-idealist understanding of tragedy, Schiller and Shelley also exemplify its tendency to reach for a metaphysical formulation of tragic experience. The notion that the experience of tragedy is fundamentally metaphysical is spread throughout the writings of German idealism and romanticism. ${ }^{88}$ In Nietzsche and Schopenhauer, the

${ }^{87}$ Though Schiller too, it may be noted, acknowledges that Milton's Lucifer 'fills us with a feeling of amazement' ('On the pathetic', p. 60).

${ }^{88}$ There is evidently a close relation between tragic insight, under the Nietzschean interpretation, and the ethos of romanticism (to the extent that such a unitary thing can be supposed to exist). The relation of the tragic outlook to romanticism is however complex, as can be seen from the following two quotations: 'Romanticism always consciously refused to recognize tragedy as a form of life (though not, of course, as a form of literary creation). The highest aspiration of Romanticism was to make tragedy disappear completely from the world, to resolve tragic situations in an untragic way' (Lukács, 'On the romantic philosophy of life', in Soul and Form, p. 51); 'The distinguishing feature of the metaphysical theory which underlies romanticism is that it rejects the inevitable victory or inherence of these [Christian, moral] ideals without rejecting the ideals themselves [...]

Romanticism, the belief in the human conflict against the Universe and against power, seems to me to be the driving force of all art [...] The ethical content of romanticism has always been the same. The romantic bases his ethic upon his belief in the hostility or the neutrality of the Universe' (Alex Comfort, 'The ideology of romanticism', in Robert F. Gleckner and Gerald E. Enscoe eds., Romanticism: Points of View, 2nd edn. (Englewood Cliffs, N.J.: Prentice-Hall, 1970), pp. 169-70). Neither of the two assessments, which partly agree and partly disagree, is beyond dispute, but each has a good claim to capture one aspect of romanticism. 
metaphysical content is conceived of as including a monistic and trans-individual element. Hegel's theory of the content of tragedy, though up to a point employing only moral-cultural materials, depends ultimately, as argued earlier, on speculative metaphysics. In Schiller's conception the metaphysical content of tragedy is located in the individualised subject: tragedy displays through its stripping away of sensuous being a non-empirical essence, 'a principle that is incomparably great and infinite ${ }^{89}$ Similarly in Johann Wolfgang von Goethe, ${ }^{90}$ A. W. Schlegel, ${ }^{91}$ Samuel Taylor Coleridge ${ }^{92}$ and twentieth-century legatees of German idealism such as Georg Lukács. ${ }^{93}$

89 'On the pathetic', p. $65 \mathrm{n}$.

${ }^{90}$ See the extract from 'Shakespeare and no end', in Bate ed., The Romantics on Shakespeare, pp. $71-5$.

${ }^{91}$ Lectures on Dramatic Art and Literature (1809-11), vol. 1, trans. John Black (London: Baldwin, 1815), Lecture II, pp. 40-2: the fact that reason necessitates our referring ourselves to an ever-higher goal generates a demand for the infinite, in the light of which our finite, dependent, mortal existence seems transitory and null - this being the 'tragic tone'. Lecture III, pp. 72-4: pleasure in tragedy derives from our concern with human dignity, a higher order and a spiritual invisible power; the instructive aim of tragedy is to 'establish the claims of the mind to a divine origin': 'tragical poetry wished wholly to separate the image of humanity [...] from the ground of nature to which man is in reality chained [...] the Greeks achieved an elevation more than human $[\ldots]$ the feeling of dignity elevates man [...] absolves him from the guardianship of nature'. On pp. 75-6 Schlegel rejects the moral view of tragedy. See also Schlegel's 'Vorlesungen über philosophische Kunstlehre. Jena 1798', in Kritische Ausgabe der Vorlesungen, vol. 1, Vorlesungen über Ästhetik I [1798-1803], ed. Ernst Behler (Paderborn: Schöningh, 1989), §§212-18, emphasising the opposition of freedom and extra-natural necessity in tragedy; in $\$ 212$ (p. 84) Schlegel denies that a moral aim pertains to the essence of tragedy.

${ }^{92}$ See Biographia Literaria: or Biographical Sketches of My Literary Life and Opinions (London: Dent, 1975), p. 192 n1, and Criticism of Shakespeare, pp. 43-4.

93 'The metaphysics of tragedy'. 
It is however Friedrich Hölderlin who represents perhaps the purest case of a metaphysical theory of tragedy. Hölderlin's theoretical writings on poetry, ${ }^{94}$ though extremely fragmented, contain sufficient indications of the broad kind of account of tragedy he wishes to give. The recurrent themes that occupy Hölderlin are 'inwardness', 'life in general', apotheosised in 'pure poetic life', 'divinity' and 'destiny' ${ }^{95}$ His aim is to identify tragedy with a 'mood' or 'image', a state of soul or a vision; ${ }^{96}$ he considers that, though tragedy can be rendered artistically in narrative

${ }^{94}$ Essays and Letters on Theory, trans. and ed. Thomas Pfau (Albany: State University of New York Press, 1988). On Hölderlin, see Françoise Dastur, 'Tragedy and speculation', in Miguel de Beistegui and Simon Sparks eds., Philosophy and Tragedy (London: Routledge, 2000), and Dieter Henrich, The Course of Remembrance and Other Essays on Hölderlin, ed. Eckart Förster (Stanford, California: Stanford University Press, 1997), pp. 117-18, 133-6.

${ }^{95}$ See Essays and Letters, pp. 51-7, 67, 107, 113-14.

96 The tendency of Hölderlin's aesthetic is thus to erode the distinction between tragedy and lyric poetry and, indeed, between poetry and art in general. It reaches its conclusion in some late descendants of the German idealist tradition in aesthetics, where we find opposition to any doctrine of artistic differentiation and an accompanying denial that tragedy constitutes a genuine aesthetic or artistic kind: see Benedetto Croce, Aesthetic as Science of Expression and General Linguistic (1902), trans. Colin Lyas (Cambridge: Cambridge University Press, 1990), ch. 12, and R. G. Collingwood, The Principles of Art (1937) (Oxford: Oxford University Press, 1978), pp. 51-2, 11516. This is not, in any case, Hölderlin's position. One, extremely important, advantage of identifying tragedy at Hölderlin's supra-narrative level is that it makes it intelligible that tragedy can be expressed in literary forms that are virtually without narrative (Samuel Beckett) and in other, non-representational forms of art (music, non-figurative painting, e.g. Rothko); in other words, it unifies tragedy as a genre with works that express tragic feeling. Modern critical practice in some places follows this view; see, for example, Wilson G. Knight's 'spatial' interpretations of 
representational form, it is not essentially an empirical sequence, for which reason Hölderlin speaks of 'tragic time' in contrast with 'human time'. ${ }^{97}$ The mood or image in question concerns a metaphysical object, more precisely, a transcendental movement. Hölderlin conceives tragedy as symbolising or in some fashion enacting the overcoming of the division of subject and object: the tragic is, he says, 'the metaphor of an intellectual intuition', ${ }^{98}$ the intuition of a primordial living unity prior to the separation of subject and object, which yet results in suffering because the feeling of the whole requires itself to be felt in each of its parts, thereby 'transcend[ing] the boundary' of the parts. ${ }^{99}$ The tragic affirmation consists in a return to this original unity, or a new form of it. ${ }^{100}$ The form of human life, the concept of destiny, and the metaphysical division of subject and object, are thus for Hölderlin aligned in tragedy: the tragic rests on 'boundless union purifying itself through boundless separation'; ${ }^{101}$ tragic suffering effects a reduction to the form of human life in general; ${ }^{102}$ tragic protagonists 'are all more or less attempts to solve the problem of destiny',

Shakespearian tragedy in The Wheel of Fire: Interpretations of Shakespearian Tragedy (London: Methuen, 1961).

${ }^{97}$ Essays and Letters, p. 114. The same or a parallel notion is in Lukács, 'The metaphysics of tragedy', pp. 158-9.

${ }^{98}$ Op. cit., p. 83.

${ }^{99}$ Op. cit., pp. 84-6.

${ }^{100}$ Op. cit.: 'at this birth of the highest hostility the highest reconciliation appears to be the case' (p. 54); 'the separation proceeds until the parts are in their most extreme tension, where they resist one another most strongly. From this conflict, it returns into itself [...] a new unity originates' (p. 86).

${ }^{101}$ Op. cit., p. 107.

102 'In the utmost form of suffering, namely, there exists nothing but the conditions of time and space', op. cit. p. 108. 
'cancelled to the extent that they are not universally valid'. ${ }^{103}$ Though it is too undeveloped for one to be sure, Hölderlin's theory appears to come close to providing the 'super'-perspective described earlier, one that reconciles tragedy with morality on terms dictated by the former.

The two final theories that I wish to review, Schopenhauer's and F. W. J. von Schelling's, are again metaphysical, but distinguished from those already discussed by the distinctive manner in which they handle the relation of tragedy to morality.

On Schopenhauer's account, ${ }^{104}$ tragedy is privileged metaphysically as an artistic genre, in the way that music is privileged as a form of art. Indeed, the ultimate representational content of tragedy - its exhibition of the human world-as-representation as a self-manifestation of will corresponds closely to the metaphysical truth - the intuition of the blind will that comprises the world's underlying reality - which on Schopenhauer's theory is provided by music; and the conative-affective state which Schopenhauer designates as the proper effect of music, the placidity of pure will-less contemplation, corresponds to the state of resignation which Schopenhauer regards as the proper response to tragedy and with which he identifies tragedy's affirmative moment. The prima facie implications of such an account are, very clearly, that tragedy is indifferent to morality, and this is reflected in Schopenhauer's firm rejection of the principle of poetic justice. ${ }^{105}$

More precisely, Schopenhauer's account of the metaphysical truth expressed in tragedy would appear to carry nihilistic implications: to the extent that all states of persons are regarded as just so many perturbations of will, the very idea of a reason for action seems to disappear, and with it the idea that morality has any special claim. This marks a difference from Schiller and Shelley: the conflict of tragedy with morality is here located in the negative, rather than the affirmative

${ }^{103}$ Op. cit., p. 57.

${ }^{104}$ The World as Will and Representation, vol. 1, pp. 252-5, 322, 331, 393, and vol. 2, pp. 240, 4337, 630 . ${ }^{105}$ Op. cit., vol. 1, pp. 253-4. 
moment of tragedy, and in a global cancellation of the notion of rational action, as opposed to awareness of a special, elevated species of value.

Schopenhauer's philosophy contains, however, two further elements which serve to block the nihilistic prima facie implications of his account of tragedy, and which ultimately re-attune tragedy with morality: an ethics of compassion, and a quasi-Augustinian doctrine that human existence is itself sin. According to Schopenhauer, the motive to morality reposes on the metaphysical insight that personal individuation is an illusion, and since this insight is broadly the same as that which is expressed in tragedy, the morality-paralysing implications of tragedy are neutralised: the reasons for action which the tragic vision eliminates are in fact not, according to Schopenhauer, presupposed by morality; on the contrary, tragic vision may be expected to bolster moral motivation.

Second, Schopenhauer holds that the experience of tragedy, after initially displaying the world as the scene of will's self-antagonism, leads us ultimately to a judgement of 'eternal justice': we are brought to recognise that a fault is involved in the very individuated existence of the self, and consequently that there is a rightness to its tragic destruction. ${ }^{106}$ Schopenhauer's theory, after seeming to set tragedy at a clear distance from morality, thus remoralises it at the last hurdle.

Though the coherence of Schopenhauer's ethics is not a question for the theory of tragedy, the second part of his account can certainly be challenged by appeal to the experience of tragedy. It is in the first place doubtful that the affirmative moment of tragedy can be understood on the basis of a switch to resignation, as Schopenhauer proposes, since resignation appears to contain no affirmation; as Schopenhauer appears to recognise, for he introduces the distinct and further idea that tragedy 'demands an existence of a different kind, a different world', ${ }^{107}$ in order to supply an

\footnotetext{
${ }^{106}$ Op. cit., vol. 1, pp. 254, 331; see also $§ 63$.

${ }^{107}$ Op. cit., vol. 2, pp. 433, 435. See M. S. Silk and J. P. Stern, Nietzsche's Theory of Tragedy

(Cambridge: Cambridge University Press, 1981), pp. 329-31.
} 
object of affirmation. This solution is unsatisfactory, however, in so far as nothing is actually provided within tragedy to suggest the reality of this, merely demanded, different form of existence. In any case, the notion that we can regard the tragic process as a whole which is 'just' or has a justification, in a sense positively related to that in which the moral justice of an action provides it with a justification, seems to demand, exactly as does Hegel's theory, the occupation of a point of view directly contrary to that individual, restrictedly human standpoint which is constitutive of the experience of tragedy. Philosophical reflection may well be able to take up the standpoint of the will, justifiably destroying individuality in order to return to itself; but it is a different matter, and implausible, to suppose that the bridge to this standpoint is presented within the experience of tragedy.

Schelling's theory of tragedy distinguishes itself as the most subtle and sensitive attempt in German idealism to square tragedy with morality. ${ }^{108}$ The idealist-romantic theories examined so far proceed by identifying different aspects of human personality corresponding to the negative and affirmative moments in tragedy: tragedy is viewed as an ablative process in which one part of the self is destroyed and the other, higher part preserved. Schelling, by contrast, with a stronger sense of the unity of tragic experience, attempts to conceive the two sides of the tragic process - the negative moment in which the world afflicts the subject with loss and suffering, and the contrary moment where the subject is affirmed in the teeth of the world - as identical. Schelling describes the tragic opposition of human subject and world as an opposition of freedom and necessity, and tragedy as portraying:

${ }^{108}$ Philosophical Letters, pp. 192-4, The Philosophy of Art, pp. 247-80. On Schelling, see Peter Szondi, 'The notion of the tragic in Schelling, Hölderlin and Hegel', in On Textual Understanding and Other Essays, trans. Harvey Mendelsohn (Manchester: Manchester University Press, 1986). 
necessity genuinely caught in a struggle with freedom, yet such that a balance obtains between the two [...] both, necessity and freedom, emerge from this struggle simultaneously as victorious and vanquished, and accordingly equal in every respect. But precisely this is doubtlessly the highest manifestation of art, namely, that freedom elevate itself to a position of equity with necessity, and that necessity appear as the equal of freedom without the latter losing in significance in the process [...] The essence of tragedy is thus an actual and objective conflict between freedom in the subject on the one hand, and necessity on the other, a conflict that does not end such that one or the other succumbs, but rather such that both are manifested in perfect indifference as simultaneously victorious and vanquished. ${ }^{109}$

Schelling, like Schiller, philosophises within Kant's framework, and regards the opposition of freedom and nature as philosophically fundamental. But there is a deep difference in approach. Schiller views the Kantian structure of freedom and nature primarily from the practical standpoint, from which it is grasped as setting the parameters and defining the task of practical reason. From this stems Schiller's pronouncedly moral view of tragedy. Schelling, by contrast, aims to step beyond the practical perspective which, on his account, permits only a partial grasp of the relation of freedom and necessity, in order to achieve an objective and comprehensive view of their relation. The philosophical task of articulating this relation is, moreover, subordinate to and dependent on the intuition of their relation which art alone can provide. ${ }^{110}$ This is what allows Schelling to

${ }^{109}$ The Philosophy of Art, pp. 249, 251.

110 System of Transcendental Idealism (1800), trans. Peter Heath (Charlottesville: University Press of Virginia, 1993), pt. VI, and The Philosophy of Art, pt. I. 
provide an account of tragedy which is more accurate than Schiller's, and which, though also constructed out of Kantian materials, makes the interest of tragedy independent of morality. ${ }^{111}$

However, though no reference to morality occurs in Schelling's basic theory of tragedy, a moral characterisation is later introduced, and it produces the same straining of moral concepts as seen in Schopenhauer's notion that tragic loss atones for the 'guilt' of existence. The tragic protagonist, Schelling supposes, falls into misfortune as a result of error, and yet 'is necessarily guilty of transgression': 'This is the highest possible misfortune: by fate to become guilty without genuine guilt.' ${ }^{112}$ The guilt is contracted through fate, the absolute, non-empirically necessity that lies in the world and stands opposed to the subject's freedom: 'fate itself makes the guilty person into a transgressor', the protagonist choosing to 'atone voluntarily' for the 'guilt imposed by fate itself' ${ }^{113}$

Schelling speaks as if this formula simply follows from his conception of tragedy as an identity of freedom and necessity, but it does not, and it is not similarly intelligible. What makes it reasonable, from within the perspective of tragedy, to regard tragedy as an identity of freedom and necessity, is the fact that we do, in fact, experience the negative and affirmative moments of tragedy as enjoying a strangely intimate relation. There is, however, nothing analogous in the experience of

${ }^{111}$ See Silk and Stern, Nietzsche's Theory of Tragedy, p. 312: 'more than any other modern theorist it is Schelling, with his emphasis on the existential problems of das Tragische (as against the dramatic problems of tragedy), who anticipates Nietzsche's views [...] a close kinship exists between Schelling's antinomian attribution of value to the single man in his "tragic" predicament and Nietzsche's Dionysiac amoralism'.

112 The Philosophy of Art, p. 252.

${ }^{113}$ Op. cit., pp. 253-4. (In a much later writing, in On the History of Modern Philosophy (1856-61), trans. Andrew Bowie (Cambridge: Cambridge University Press, 1994), p. 128, Schelling reverts even further to neo-classical orthodoxy, saying that tragedy exhibits a 'wise Providence'.) 
tragedy which allows us to make sense of the idea that innocence can be converted into guilt through a sheer act of choice - as opposed to the more plausible idea that the hero experiences himself as transported beyond questions of guilt and responsibility. Whatever intelligibility Schelling's notion may have, it must derive from other parts of his philosophy. Again it may be said - as in the case of Hegel and Schopenhauer's speculative unifications of tragedy with morality that the moral element in Schelling's account of tragedy may be justifiable, but it cannot be extracted from, and it is not directly supported by, the experience of tragedy itself.

What distinguishes the theories of Schopenhauer and Schelling, then, is the way that they seem initially to dissociate tragedy from morality, but then ultimately return to a moral view of tragedy. The common difficulty which they face in discovering a moral meaning in tragedy confirms the view that tragedy and morality comprise incompatible perspectives. When we try to superimpose the perspectives of morality and tragedy, to occupy both at the same time, the result is confusion - as manifest in the doctrine that the existence of the self is a sin and its destruction is just, or that I can elect to be responsible for that which I am not responsible. Not only do these ideas fail to illuminate the experience of tragedy, moral reflection cannot make sense of them either. We should instead regard tragedy and morality as defining different worlds: in the tragic perspective we apprehend morality simply as part of the complex of forces which move human agents and shape human existence, while from the moral perspective all that can be seen in tragedy is a set of evils susceptible to and requiring moral compensation. ${ }^{114}$

It should be clear how all of the metaphysical theories referred to map onto the conception of tragedy as a formal intuition of human life. In terms of the schema suggested earlier, Nietzsche's

\footnotetext{
${ }^{114}$ We can now see that the naive, neo-classical interpretation of tragedy as representing the execution of poetical Justice, though untenable, is well-conceived in the sense that, in contrast with the sophisticated versions of the moral view found in German idealism, it grasps accurately what would be required for tragedy to conform to moral consciousness.
} 
Dyonisiac corresponds to the background against which the form of human life appears, and his Apolline principle to the human figure's distinction from its ground. Schopenhauer's selfantagonistic will, and Hölderlin's drama of subject-object differentiation, correspond to the movement whereby the figure differentiates itself from the ground; in Schiller, and Shelley, the sense-transcendent self-affirmation corresponds to the figure's experience of self-differentiation. Schelling's identity of freedom and necessity characterises the relation of figure to ground as simultaneously one of distinctness and inclusion.

In addition, a pattern reveals itself with respect to these idealist-romantic theories of tragedy. In each case it is possible to isolate an element in the theory which corresponds to the hypothesis that tragedy expresses an indeterminate intuition of the form of human life, and to separate this element from the further interpretation which the theory puts on the intuition and which renders the meaning of tragedy philosophically determinate. With respect to the latter, what I wish to maintain is not that the attempt to fix determinately the meaning of tragedy is itself in error, but that, first, the determinate meanings which the theories assign to tragedy cannot be extrapolated directly from the tragic experience itself, and so must owe whatever authority they possess to the philosophical systems from which they are drawn, and second, that the attempt to render the meaning of tragedy determinate goes awry when it pushes tragedy in the direction of a moral meaning. There is, therefore, a line of continuity in German idealist and romantic reflections on tragedy, which veers towards Nietzsche's view of relation of tragedy and morality, and which can be explained on the assumption that the fundamental content of tragedy is an intuition of the indeterminate form of human life, that comes to be determined in different ways on the various theories of tragedy. These two strands are, furthermore, connected: although there can be metaphysical theories of tragedy which affirm the moral view, such as Hegel's, the deepest and most accurate insights into the metaphysical content of tragedy are ones which pull it apart from morality, vindicating Nietzsche's view of their relationship. In historical terms, though it would be false to claim that romanticism 
broke with the moral view of tragedy, its major shifts of emphasis in the understanding of tragedy are what opened the door to the development of the non-moral, Nietzschean view.

Bradley observes that 'it is extremely hard to make out exactly what this experience [of tragedy] is, because, in the very effort to make it out, our reflecting mind, full of everyday ideas, is always tending to transform it by the application of these ideas, and so elicit a result which, instead of representing the fact, conventionalises it'. ${ }^{115}$ Countering this tendency, Bradley insists that tragedy presents us with a 'mystery', an 'inexplicable fact'. 116

I have tried to show that the moral view of tragedy is an instance of the conventionalisation described by Bradley. Whether he is right to regard tragedy as essentially incomprehensible is, however, a further question. If Bradley is right, then any theory which seeks to explain tragedy is misguided. The moral view, as found in Schiller for example, is then wrong twice over: by virtue of the particular kind of explanation that it offers, and by virtue of its attempting a complete explanation of tragedy at all. The idea that tragedy is incomprehensible sits uneasily, however, with

\section{Shakespearean Tragedy, p. 17.}

116 Op. cit., p. 29. See also Northrop Frye, Anatomy of Criticism: Four Essays (Princeton, NJ:

Princeton University Press, 1971), pp. 284-5: ‘tragedy shows itself to be primarily a vision of the supremacy of the event or mythos. The response to tragedy is "this must be', or, perhaps more accurately, “this does happen"': the event is primary, the explanation of it secondary and variable.' See also Hans-Georg Gadamer, Truth and Method (1975), 2nd \& revised edn. (1989), trans. Joel Weinsheimer and Donald G. Marshall (Shed \& Ward: London, 1993), pp. 129-34, agreeing that tragedy pertains to 'a metaphysical order of being which is true for all' (p. 132) and which has nothing to do with a 'moral world order' (p. 131). (Gadamer's positive account of what specifically distinguishes and is affirmed in tragedy - as opposed to his account of the general conditions for art - is hard to locate, however.) 
the claim that tragedy is deeply important: an experience which refused all insight would be consigned to a category of psychological aberrations. Consequently it seems better to express Bradley's idea by saying that the only acceptable kind of 'explanation' of tragedy is one that falls short of completeness, i.e. that merely defers to an appropriate point the ultimate inexplicability of tragedy - an explanation that, as Kant says of his theory of human freedom, merely renders comprehensible its incomprehensibility. The account I have suggested does this, by postulating, without pretending to explain, an object the intuition of which is inseparable from its affirmation. With this or some other appropriate metaphysical notion, I have argued, some light may be thrown on the 'inexplicable fact' presented in our experience of tragedy. ${ }^{117}$

${ }^{117}$ I am grateful to Neil Vickers for help in writing this paper, and wish to acknowledge the assistance of the Arts and Humanities Research Board and the Department of Philosophy of University College London, who facilitated the research leave during which this paper was completed. 